\title{
FELIX COHEN AND THE SPANISH MOMENT IN FEDERAL INDIAN LAW: A STUDY IN LAW, POLITICS AND HISTORIOGRAPHY
}

\author{
R P Boast ${ }^{*}$
}

One of the best-known discussions of the historical foundations of native title law is Felix Cohen's famous paper on the Spanish Origins of Federal Indian Law, published originally in 1942 and since then reprinted many times.

This article cites Cohen's paper in its political and historiographical context, paying particular attention to Cohen's role as one of the architects of the Indian Reorganisation Act of 1934, and considering also shifts in American historiography and legal writing relating to the Spanish legacy as exemplified by legal historians such as James Brown Scott and historians such as $H$ E Bolton. This article also considers fully Cohen's analysis of the precise ways in which Spanish law penetrated the legal framework of Federal Indian Law in the United States and concludes that, as a historical discussion, Cohen's work is in need of substantial revision. In particular Cohen's arguments that Spanish law influenced federal Indian law via international law and by means of judicial consideration of old Spanish land claims seem difficult to sustain.

\section{THE SPANISH LEGACY: CRITICS AND ENTHUSIASTS}

\section{A Introduction}

Felix Cohen's article on the Spanish origins of Federal Indian law, which will be the principal text analysed here, was originally published in $1942 .{ }^{1}$ It is a classic discussion, and exemplifies what can be seen as a "Spanish moment" in the long history of Federal Indian law in the United States. Cohen's famous article has been relied on by many writers and scholars who celebrate - as

* Reader in Law, Victoria University of Wellington.

1 Felix S Cohen "The Spanish Origin of Indian Rights in the Law of the United States" (1942) 31 Geo LJ 1 [Cohen "Spanish Origin"]. At the time of publication Cohen held the position of Chairman of the Board of Appeals, Department of the Interior. 
well as by some who condemn - the supposed Spanish foundations of American Indian law. Robert Williams, an unabashed opponent of the whole edifice of Federal Indian law, which he regards as basically "racist", nevertheless sees Cohen as "the single most influential scholar to have written on US-Indian legal relations". 2 "Spanish Origin" is undoubtedly one of the most-cited United States law review articles on Federal Indian law ever written. It is certainly well-known and frequently read outside the United States. In evaluating Cohen's article today, however, it must be remembered that it was written at a very special time in American history. It cannot be separated from its context of the Second World War, of the Indian New Deal, and of the (regrettably short-lived) "Good Neighbour" Policy between the United States and Latin America. Building on a revalorisation of the Spanish contribution to American history and Indian law, "Spanish Origin" seems in retrospect to be essentially a policy-oriented piece aimed at building and developing support for the antiassimilationist policies of the Indian Reorganization Act of 1934 (IRA).

To say this is not meant as a criticism of the actual policies pursued during the period of the Indian New Deal, policies that were eminently praiseworthy in many ways - although it has to be admitted that the Indian New Deal, and its principal architect, John Collier, Cohen's superior at the Department of the Interior, certainly has its critics as well as its defenders. ${ }^{3}$ (Even the critics, on the whole, concede that the Indian New Deal was a major improvement compared both with what came before and what came afterwards. $)^{4}$ This article aspires also to clarify aspects of those policies by setting them, if not in a "Spanish" context, at least in a Latin American one. The Latin American dimension of the Indian New Deal was, highly significant and is worthy of more sustained investigation than it has received. Such an investigation however involves the challenging mental effort of re-imagining a time and period when a revitalisation of customary indigenous tenures by a staunchly socialist government in Mexico could evoke warm enthusiasm, praise and even emulation

2 Robert A Williams Jr "The Medieval and Renaissance Origins of the Status of the American Indian in Western Legal Thought" (1983-1984) 57 S Cal L Rev 1, 1, n 1. Williams prefaces his article with a quotation from Felix Cohen's article and claims that "while not consciously intended as a mere continuation of Cohen's efforts, this Article is meant to provide a further examination of the 'curious historical patchwork' of sources that continue, even as in Cohen's time, to shape the fabric of our own modern federal Indian law" (ibid).

3 Critical interpretations include Russel Lawrence Barsh and James Youngblood Henderson The Road: Indian Tribes and Political Liberty (University of California Press, Berkeley, 1980); Lawrence C Kelly "The Indian Reorganization Act: The Dream and the Reality" (1975) 44 The Pacific Historical Review 291; for vigorous defences see Clayton Koppes "From New Deal to Termination: Liberalism and Indian Policy, 1933-1953" (1977) 46 The Pacific Historical Review 543; Elmer Rusco "John Collier: Architect of Sovereignty or Assimilation?" (1991) 15 American Indian Quarterly 49; Wilcomb E Washburn "A FiftyYear Perspective on the Indian Reorganization Act" (1984) 86 American Anthropologist (New Series) 279. Washburn writes that he "would ask anthropologists critical of the Collier approach to explain what achievements they can point to that compare with his, or that do not actually and necessarily build on the foundation he created": ibid, 288.

4 See for example Kelly "Indian Reorganization Act", ibid. 
by highly-placed officials in the United States. One needs to imagine away, therefore, the CIA and Guatemala, Castro, the Bay of Pigs and some recent sabre-rattling over President Chávez of Venezuela to return to a more idealistic and optimistic time, one the world could still maybe learn from.

The sixteenth-century Spanish theologians and activists Francisco de Vítoria, Bartolomé de las Casas, Francisco Suárez and the thinkers and teachers of that time have of course many admirers today. ${ }^{5}$ That Catholic writers and law professors within the natural law tradition in both Europe and the United States would find much to admire in Vítoria and Suárez - they tend to be rather less enthusiastic about the furiously energetic and activist Las Casas, an unrelenting critic of Spanish behaviour and policy ${ }^{6}$ - is not surprising. What is surprising, on the face of things, is the apparent appeal of a $16^{\text {th }}$ century Spanish Aristotelian theologian like Vítoria to a classic New Deal liberal, intellectual and enlightened official such as Felix Cohen. Vítoria was after all a product of the Spain which expelled all Jews in 1492, which repressed dissent by means of the Spanish inquisition, and which pursued policies in the New World which, however unjustifiably, have become a byword for cruelty and oppression of indigenous populations. As a leading legal realist, Cohen's enthusiasm for a quintessential Aristotelian Catholic theologian like Vitoria, one of the patron saints of the naturalist camp, is a bit of a puzzle. Yet, it will be shown, in fact in its time and place Cohen's

5 For an accessible collection of Vítoria's main writings see Anthony Pagden and Jeremy Lawrence (eds) Vítoria - Political Writings (Cambridge University Press, Cambridge, 1991). Modern admirers of Vítoria within the naturalist tradition include Robert John Araujo SJ "The Catholic Neo-Scholastic Contribution to Human Rights" (2003) 1 Ave Maria Law Review 159; Thomas C Donohue SJ "Vitoria's Universalism and the Rule of Law" (1960) 6 Catholic Lawyer 200; James Muldoon "A Canonistic Contribution to the Formation of International Law" (1968) 28 The Jurist 265; Joseph M de Torre "The Roots of International Law and the Teachings of Francisco de Vitoria as a Foundation for Transcendent Human Rights and Global Peace" (2004) 4 Ave Maria Law Review 123. My own paper should not be seen as an attack on naturalism as such, but some of the scholars cited do make rather large claims: see for example Torre, ibid, 139 (footnotes omitted):

Vitoria courageously expounded the fundamental equality of all human beings and acknowledged that the ultimate sovereignty of the people is given to them by God. He spelled out the inviolable rights to life, to liberty, and to self-rule, including the right to private economic initiative and to participation in public life. In Francisco de Vitoria's writings, we find the first virtually complete enumeration of human rights and principles of democratic government and law, both on a national and international level, long before the American Declaration of Independence and Thomas Paine's Rights of Man.

As for Las Casas, there is a vast literature. Unlike Vítoria, who published nothing in his own lifetime, Las Casas wrote and published an astounding amount. The leading writer in English on Las Casas is Lewis Hanke. For an accessible introduction see Anthony Pagden "Ius et Factum: Text and Experience in the Writings of Bartolomé de Las Casas" (1991) 33 Representations 147.

6 See Lewis Hanke "More Heat and Some Light on the Spanish Struggle for Justice in the Conquest of America" (1964) 44 The Hispanic American Historical Review 293 (reviewing various texts on Las Casas in Spanish). 
attempt to emphasise the "Spanish origins" of Indian law in the United States - and by implication in the common law world generally, to a lesser extent - is readily understandable.

Before proceeding further, however, an obvious fact must be registered: the political formation that is now the United States was of course founded not by the Spanish but by the English; and surely it is in English ideologies and in English legal thought that the foundations of the modern structures of American Federal Indian law are most likely to be found. ${ }^{7}$ Most historians would think so, and indeed there is a large literature exploring these links. While the field of the Spanish, or more precisely Hispanic, dimension to American history is certainly flourishing at the present time, it is hard to think of any historians who would see Federal Indian law as being marked in any significant way by specifically Spanish ideas. Any similarities between the general structures of "Spanish" and "American" law are more likely to derive from a common framework originating in a common Renaissance intellectual culture that Spain and England once shared. Such, at least, is my opinion, but Cohen's argument that Federal Indian law derives in part from international law, and that international law was indeed created by $16^{\text {th }}$ century Spanish intellectuals, nevertheless is of great interest and of some plausibility. This point will be returned to later.

\section{B "La Leyenda Negra" in American Historiography}

Until the 1920s Americans saw Spanish history, and Spanish-American history, through the lens of the "Black Legend", la leyenda negra, by which Spain herself is seen as typified by the worst excesses of Catholic bigotry, symbolised by the Spanish Inquisition, and the history of the Spanish colonial empire as the ultimate in cruelty, oppression, backwardness and exploitation. That this attitude remains entrenched in the Anglo-Saxon mind is obvious to anyone who teaches a course on Spanish colonial history in an English-speaking university to this day. Attempts to convince students that there was another side to the coin have to overcome a high threshold of scepticism, not

7 On the ideological underpinnings of English colonisation see especially Andrew Fitzmaurice Humanism in America: An Intellectual History of English Colonization (Cambridge University Press, Cambridge, 2003) (arguing that there were links between civic humanism, colonisation theory in Tudor and early-Stuart England, the republican writers of the Interregnum and ultimately with the founders of the United States); Andrew Fitzmaurice "Classical Rhetoric and the Promotion of the New World" (1997) 58 Journal of the History of Ideas 121; and the various writings of Anthony Pagden, which cannot be done justice to in a footnote, most relevantly his Lords of all the World: Ideologies of Empire in Spain, Britain and France c.1500-c.1800 (Yale University Press, New Haven, 1995). Other important contributions from a range of perspectives - the literature is now vast - are Nicolas Canny "The Ideology of English Colonisation: From Ireland to America" (1973) 30 The William and Mary Quarterly; Nicholas Canny (ed) The Oxford History of the British Empire, Volume 1: The Origins of Empire: British Overseas Enterprise to the Close of the Seventeenth Century (Oxford University Press, Oxford and New York, 1998); Christopher Hill "The English Revolution and the Brotherhood of Man" in Christopher Hill Puritanism and Revolution: Studies in Interpretation of the English Revolution of the $17^{\text {th }}$ Century (Secker and Warburg, London, 1958) 126 (some undeservedly neglected ideas); Daniel Hulseboch "The Ancient Constitution and the Expanding Empire: Sir Edward Coke's British Jurisprudence" (2003) 21 Law \& Hist Rev 439; Dane Kennedy "Imperial History and Post-Colonial Theory" (1996) 24 Journal of Imperial and Commonwealth History 345. 
to say incredulity. To a very significant extent la leyenda negra was actually created by the Spanish themselves, or at least by some Spaniards (Las Casas especially), but its popularity in the United States no doubt derived from anti-Spanish prejudices inherited from the English and powerfully reinforced by the history of United States expansion westwards during the $19^{\text {th }}$ century.

The United States was a competitor with Spain, and then with Mexico, for territory and natural resources in the western hemisphere in the $19^{\text {th }}$ century. This made it all the more tempting for North Americans to equate themselves with modernity and progress and the Spanish world with backwardness and misgovernment. The aggressively Protestant political culture of the nineteenthcentury United States provided a theological, or at least ideological, dimension to competition with Hispanic America. These attitudes, which have been explored by many sophisticated historians, also impacted on the writing of history in the $19^{\text {th }}$ century United States. ${ }^{8}$ Nineteenth century North American writing on the history of the Spanish empire focused on "a limited number of themes, among which the discovery by Columbus and the two conquests by Cortés and Pizarro predominated". 9 This fitted with the leyenda negra and the "gold and God" stereotype: seeing Latin American history as dominated by conquest "especially fit the familiar conception of Hispanic America as a land that had never fully emerged from the brutality of its colonial past". ${ }^{10}$ William Hickling Prescott's classic studies of the conquests of Mexico and Peru exemplify this tradition. North Americans on the whole saw little of value in Spanish colonial history. ${ }^{11}$

It was in California, a state with its own Hispanic history, that this tradition first came under sustained challenge in the $20^{\text {th }}$ century. A key group of historians who attacked the leyenda negra

8 On the earlier historiography of American writing on Spain and Spanish America see especially Charles Gibson and Benjamin Keen "Trends of United States Studies in Latin American History" (1957) 62 The American Historical Review 855 [Gibson and Keen "Trends"]; Hanke, above n 6; Benjamin Keen "Recent Writing on the Spanish Conquest" (1985) 20 Latin American Research Review 161; Benjamin Keen "Main Currents in United States Writings on Colonial Spanish America" (1985) 65 The Hispanic American Historical Review 657.

9 Gibson and Keen "Trends", above n 8, 855.

10 Ibid, 856.

11 See David Weber The Spanish Frontier in North America (Yale University Press, New Haven and London, 1992) 336. Weber makes the important point that there were marked regional variations in attitude towards Spain and the Spanish legacy in the United States. Racial mixing was one important factor in the formation of North American attitudes. "Throughout much of the nineteenth century", Weber writes, "Anglo Americans generally regarded racial mixing as a violation of the laws of nature", a prejudice which powerfully impacted on American attitudes towards the mestizo population of New Mexico": ibid, 337. In the southeastern United States Americans held a romantic and reasonably positive attitude towards the early Spanish history of Florida and Louisiana, but things were different in the southwest, and especially in Texas. The reason for this difference is obviously that in the southwest people of Hispanic descent still formed an obstacle to United States expansionism and it was there that the Black Legend proved most enduring: ibid, 339. Matters were especially contested in Texas. According to Weber, "Hispanophobia found its most strident and enduring rhetoric in Texas", ibid. 
were, and are, the historians of the so-called "Spanish borderlands". To some extent this historiography involves an effort to re-imagine the history of the United States, and to give a prominence to the Hispanic dimension to the long colonial history of the American southwest and Florida. Far from being a story of the expansion of an essentially British Isles-based culture westwards into empty lands, in fact much of the west was already under the authority of another colonial power, Spain, one which has strongly marked the cultures, history, lifeways and art of much of the present-day United States, a comparative late-comer on the American scene. These historians have tended to emphasise the Spanish contribution either very positively, or at least in a way which is shorn of the prejudices of the leyenda negra, and which has thus contributed to a much more nuanced appreciation of American history generally. The most prominent scholar of "borderlands" history was Herbert Eugene Bolton, who taught history at Berkeley from 1911-1953 and who trained large numbers of $\mathrm{PhD}$ candidates over the years. Bolton called for historians to write an "epic of Greater America" - an enterprise, as J H Elliott puts it, "that would take as fundamental the premise that the Americas shared a common history". ${ }^{12}$ Bolton's famous essay on "The Epic of a Greater America" was published in the American Historical Review in $1933 .{ }^{13}$ Bolton became one of modern America's greatest and most celebrated historians, although in some respects he is a controversial figure today: some critics claim that he over-romanticised Spanish American history or that he neglected the role of indigenous peoples - claims which others dispute. ${ }^{14}$

$12 \mathrm{~J}$ H Elliott Empires of the Atlantic World: Britain and Spain in America, 1492-1830 (Yale University Press, New Haven, 2006) xv.

13 Herbert E Bolton "The Epic of Greater America" (1933) 38 The American Historical Review 448. See ibid, 448:

It is time for a change. The increasing importance of inter-American relations makes imperative a better understanding by each of the history and the culture of all. A synthetic view is important not alone for its present day political and commercial implications; it is quite as desirable from the standpoint of correct historiography.

14 On Bolton and his historiographical legacy see Jeremy Adelman and Stephen Aron "From Borderlands to Borders: Empires, Nation-States, and the Peoples in between in North American History" (1999) 104 The American Historical Review 814; John F Bannon "Herbert Eugene Bolton - Western Historian" (1971) 2 The Western Historical Quarterly 261 (Bannon was Bolton's most prominent student - of whom there were a great many); John F Bannon Herbert Eugene Bolton: The Historian and the Man, 1870-1953 (Arizona University Press, Tucson, 1978); John F Bannon "The Mission as a Frontier Institution: Sixty Years of Interest and Research" (1979) 10 The Western Historical Quarterly 303; Albert L Hurtado "Herbert E Bolton, Racism, and American History" (1993) 62 The Pacific Historical Review 127; Albert L Hurtado "Parkmanizing the Spanish Borderlands: Bolton, Turner, and the Historians' World" (1995) 26 The Western Historical Quarterly 149; Albert L Hurtado "Romancing the West in the Twentieth Century: The Politics of History in a Contested Region" (2001) 32 The Western Historical Quarterly 417; James A Sandos "Junípero Serra's Canonization and the Historical Record" (1988) 93 American Historical Review 1253 (Bolton, though actually from a Methodist background, assisted with the research for the canonisation process); James A Sandos "From 'Boltonlands' to 'Weberlands': the Borderlands Enter American History" (1994) 46 
Bolton set out to counter la leyenda negra. In an article on Latin American cultural achievements published in 1940 Bolton summed up the stereotypical view of Latin American history held in the United States: ${ }^{15}$

Till recently we were all taught that Spain and Portugal failed as colonizers in the New World; that the Spaniards came to America as gold-seekers, whereas the English came to build homes; that the Spaniards and Portuguese did not colonize but merely explored; that they killed off all the Indians; that Columbus discovered America, Ponce de León reached Florida, St Augustine was founded in 1565, and that was the end of Spain; that most of Spain's colonies in America were conquered by always victorious England and the United States.

Bolton had an arrestingly hemispheric sense of the American Revolution, one that linked Washington and Jefferson with Hidalgo, Bolívar and San Martín. The American Revolution lasted "half a century - from 1776 to 1826 - and it witnessed the political separation of most of America from Europe". ${ }^{16}$ Spanish America, Brazil and the United States had in common a transformative break from Europe over a revolutionary process that lasted for decades: ${ }^{17}$

The Spanish and Portuguese colonies, as well as those of England, participated in the American Revolution, an epoch which lasted, not seven years, but fifty, from 1776 to 1826. In that half century Washington freed thirteen of the thirty English colonies; Bolívar, San Martín, Hidalgo, Morelos, and Iturbide liberated the Spanish colonies, and Pedro I established the independence of Portuguese America. Thus Spanish, Portuguese and English America have the common tradition of an American struggle for independence from Europe.

American Quarterly 595; David Weber "Turner, the Boltonians, and the Borderlands" (1986) 91 The American Historical Review 66; David Weber "The Spanish Legacy in North America and the Historical Imagination" (1992) 23 The Western Historical Quarterly 5.

15 Herbert E Bolton "Some Cultural Assets of Latin America" (1940) 20 The Hispanic American Historical Review 3, 5 .

16 Herbert E Bolton "The Epic of Greater America" (1933) 38 The American Historical Review 457. Lest it be thought that Bolton was a mere enthusiast for the Hispanic world, his hemispheric vision of American history certainly included Canada. See ibid, 458:

The revolt of thirteen of the thirty British colonies laid the foundation not of one but of two English speaking nations in North America. One was the United States; the other was the Dominion of Canada. Before 1776 Canada was mainly French in race stock. The settlers who now arrived made up the first large English speaking element in the country. In the revolt of the colonies the people were far from unanimous. Only thirteen of the provinces joined, though appeals were made to all. The Maritime Provinces, Quebec, the two Floridas, and the island colonies, all stood by the mother country. Even in the thirteen a third of the people were opposed to the revolution.

17 Bolton "Some Cultural Assets", above n 14, 7. 
These words were written in 1940, and in retrospect have come to have an isolationist ring, although that was presumably not Bolton's intention necessarily - he simply wanted to re-imagine the history of the United States and rid it of its ignorant chauvinism regarding an older Hispanic America. Bolton never himself produced a hemispheric account of his Fifty-Year American Revolution, nor (as far as I am aware) has anyone else made the effort.

Not surprisingly, the new pan-Americanist vision arose principally in California, a rich and powerful state with its own Spanish heritage. The state was also remote from the older centres of American power and culture on the eastern seaboard. California was simultaneously both the heartland of Spanish revival styles in architecture and of a newly positive attitude towards the Spanish past. It was also, as David Weber notes, "the most affluent state along the continent's southern rim": 18

It could support libraries, researchers, writers, and readers as could no other state in the Southwest or the

Southeast, and it had nourished the most vigorous historical writing on Hispanic North America even

before Bolton's arrival.

The history of the "Spanish borderlands", Bolton-style, has itself now come under challenge partly from those who feel that the Boltonian school neglects the American Indians and overromanticises the Spanish, and partly from Mexican-American historians and writers who have their own very ambivalent feelings about Spain and the Spanish legacy. ${ }^{19}$ Other critics argue that Bolton on the whole failed to practise what he preached. ${ }^{20}$ Maybe so. In any event, at the time when Cohen was writing in the 1930s and 1940s Spain's contribution to American history was being perceived positively by a prominent historical school which had significantly revolutionised American perceptions of Spanish America. I cannot claim to have found any direct evidence that Felix Cohen was particularly affected by these developments in American historiography, but I would like to raise the hypothesis that the Boltonian school must nevertheless have contributed significantly to an intellectual climate which moulded Felix Cohen's own revalorisation of the Spanish contribution to American legal history.

American historiography has traditionally been seen as dominated by the debate between the Hartzians and the Turnerians: was the United States a product of its originating culture, $17^{\text {th }}$ century Protestant England, or did the United States' institutions develop rather from the frontier and the abundance of cheap land? (A similar debate over the respective influences of the frontier and the British fragment developed in New Zealand, no doubt under the stimulus of American

18 Weber Spanish Frontier in North America, above n 11, 353.

19 I hope to examine the implications of the collapse of the Boltonian vision of "borderlands" history for the legal history of indigenous people's law separately.

20 David Weber "Turner, the Boltonians, and the Borderlands" (1996) 91 The American Historical Review 66, 68. 
historiography, between W H Oliver and Keith Sinclair.) ${ }^{21}$ A new vision has emerged in recent years, an "Atlanticism", largely deriving from the special historical vision of J G A Pocock, which seeks to see Britain and English America essentially as a single civilisation in which events in the one impacted on the other. This has produced a very large literature, although there are now signs of a reaction. ${ }^{22}$ The vision of the Boltonians, as can be seen, is rather different from all of these, as it seeks to place the United States in a bigger America, the whole of America, which means principally Spanish America. Boltonian history is hemispheric rather than "Atlantic". It looks south rather than east and while it has certain conceptual difficulties of its own it does have the enormous merit of recognising that much of the territory now comprised within the political formation we call "the United States" has a colonial past that stretches back much further than the Pilgrim Fathers. This involves seeing the United States as heir not solely to an English, but also to a Spanish colonial culture, a re-imagining with some significant consequences for American identity. There has been a return to this vision by some very gifted historians recently. One outstanding treatment is that of French scholars Carmen Bernard and Serge Gruzinski, authors of a massive new multi-volume history of the colonial Americas. ${ }^{23}$ Their focus, which no doubt owes much to the distinctive French historical tradition as embodied in the Annales school and on Braudel's emphasis on the longue durée, is on the Americas as a vast zone of cultural mixing and the creation of new identities. In addition the authors have sought to create a hemispheric, or more accurately a global ${ }^{24}$ history of the Americas which relegates the colonial history of the United States firmly into second place behind a much longer history of colonial interaction in the Spanish and Portuguese colonial empires. $^{25}$ Of course, Hartzians, Turnerians, Atlanticists and neo-Boltonians are probably all right

21 See Keith Pickens "The Writing of New Zealand History: A Kuhnian Perspective" (1976-1977) 17 Historical Studies 384. Keith Sinclair A History of New Zealand (Penguin, Harmondsworth, 1959) is essentially Turnerian (stressing the frontier and the local creation of culture and identity); W H Oliver The Story of New Zealand (Faber and Faber, London, 1960) is essentially Hartzian.

22 One can hardly do justice to this literature in a footnote. See for example David Armitage "Greater Britain: A Useful Category of Historical Analysis?" (1999) 104 The American Historical Review 427 and the articles and books cited above $\mathrm{n}$ 7. A probably inevitable reaction to an emphasis on "Atlanticism" is now becoming apparent, seen for example with Brendan Simms Three Victories and a Defeat: The Rise and Fall of the First British Empire, 1714-1783 (Allen Lane/Penguin Books, London, 2007).

23 Histoire du Nouveau Monde (regrettably, not so far translated into English). Of particular importance is the second volume: Carmen Bernard and Serge Gruzinski Histoire du Nouveau Monde, tome 2: Les métissages (1550-1640) (Librarie Arthème Fayard, Paris, 1999) (Spanish translation by María Antonia Neira Bigorra: Historia del Nuevo Mundo, Tomo II, Los mestizajes (1550-1640) (Fondo de Cultura Económica, México D F, 1999): references here are to the Spanish translation, the French original not being available to me.)

24 "Global" in that, as the authors remind us, the colonial world of New Spain included also its dependency on the other side of the Pacific, the Philippines, linked to New Spain by means of the Manila galleons (which regularly crossed the great ocean from Acapulco to Manila, bringing silver bullion in exchange for Asian silks and spices). One of the first "Western" countries to receive an embassy from Japan was New Spain (Mexico).

25 See Bernard and Gruzinski Los mestizajes, above n 23, 10. 
to some extent, the United States being an enormously complex and diverse polity that defies ready analysis: the question is, rather, which perspective is the more valuable and insightful? That question is not answered here, except to advance the suggestion that Felix Cohen's vision may well have been influenced by the emergence of a new hemispheric vision of the place of the United States. Moreover, it is to be remembered that Cohen belonged to an intellectual liberal Jewish milieu in New York City and was writing at a time when Europe itself had regressed into a murderous barbarism.

\section{FELIX COHEN, JOHN COLLIER AND THE INDIAN NEW DEAL}

Felix Cohen (1907-1953) was a graduate of City College in New York (BA 1926); he held a $\mathrm{PhD}$ in philosophy from Harvard (MA 1927, PhD 1929) and a law degree from Columbia (LLB 1931). Cohen joined the Department of the Interior in 1933. Cohen worked under John Collier and with Nathan Margold and first worked in the Department as a legislative draftsman - he worked with Collier on the 1934 IRA, which ended the system of allotment (individualisation) of land on the reservations and provided for the establishment of tribal governments - and later served as Assistant and Associate Solicitor at the Department of the Interior. Cohen's other great legislative achievement was the Indian Claims Commission Act 1946 which provided a mechanism for the United States to waive sovereign immunity and be sued for damages for historic claims, ushering a process with some similarities to the Waitangi Tribunal/Crown settlement system now operating in New Zealand. ${ }^{26}$ In 1941 Cohen completed the work for which he is best known, the first edition of his monumental Handbook of Federal Indian Law, ${ }^{27}$ and in 1942 he published the famous "Spanish Origin" article in the Georgetown University Law Review. ${ }^{28}$ Philosophically, or jurisprudentially, Cohen was linked with the American Legal Realist movement of the 1930s led by Karl Llewellyn. ${ }^{29}$ Llewellyn was himself interested in the American Indians and co-authored a well-known and highly innovative study of Cheyenne customary law. ${ }^{30}$ In 1948, following the sharp reversals in Federal Indian policy after World War II, Cohen left the Department and devoted the remainder of his life to teaching, writing and the advocacy of various Indian causes.

John Collier, Commissioner of Indian Affairs Cohen's superior at the Department of the Interior, deserves much more than a brief mention. To American legal historians Collier is a key figure in the

26 On Cohen and the Indian Claims Commission Act 25 USC see Dalia Tsuk "'A Double Runner': Felix Cohen and the Indian New Deal" (2002) 22 Political and Legal Anthropology Review 48.

27 Felix S Cohen Handbook of Federal Indian Law (United States Government Printing Office, Washington, 1941) [Handbook].

28 Cohen "Spanish Origin", above n 1.

29 On Cohen's jurisprudential thought see Martin P Golding "Realism and Functionalism in the Legal Thought of Felix S Cohen" (1980-1981) 66 Cornell L Rev 1032.

30 Karl Llewellyn and E Adamson Hoebel The Cheyenne Way (Oklahoma University Press, Norman, 1941). 
history of Federal Indian law, the chief architect of IRA and the inspiration for a new era in Indian policy in the 1930s and 1940s. ${ }^{31}$ Wilcomb E Washburn has written that "Collier's work as commissioner of Indian affairs is probably the most impressive achievement in the field of applied anthropology that the discipline of anthropology can claim". ${ }^{32}$ Collier had close personal links with the Hispanic world, but his sympathies and interests were less "Spanish" than they were Mexican. In particular Collier was friendly with the Mexican archaeologist, indigenist and secular liberal reformer Manuel Gamio, who had himself received part of his training in anthropology in the United States. ${ }^{33}$ The two worked together on the Inter-American Indian Institute, established after a major international conference at Pátzuaro, Mexico, in 1940. Collier wrote that "[t]his hemisphere does not contain a broader-minded man or a spirit more devoted than Manuel Gamio". ${ }^{34}$ Gamio and Collier were both "indigenists" in the sense that they were personally committed to community life and to the values and ethics of indigenous peoples as a counterweight to what they perceived as the selfish individualism of the modern world. Indians not only had the right to their own cultures: those cultures embodied ethical ideas which were valuable in their own right. Collier had led the attack on the allotment system originally introduced into the reservations by the General Allotment (Dawes) Act of $1884 .{ }^{35} \mathrm{He}$ founded the American Indian Defense Organization in 1923 and always opposed assimilation of the American Indians. In 1933 Roosevelt appointed Collier as Commissioner of Indian Affairs, and Collier and his officials immediately began work on the legislation enacted as IRA the following year. IRA was a milestone in American legal history and many of today's Indian governments were established under it.

31 On Collier see Lawrence Kelly The Assault on Assimilation: John Collier and the Origins of Indian Policy Reform (University of New Mexico Press, Albuquerque, 1983); Kenneth R Philp John Collier's Crusade for Indian Reform (University of Arizona Press, Tucson, 1977); E A Schwartz "Red Atlantis Revisited: Community and Culture in the Writings of John Collier" (1994) 18 American Indian Quarterly 507. Collier began his career helping to organise immigrant workers in New York and was a committed New Dealer.

32 Washburn "Indian Reorganization Act", above n 3, 287.

33 Gamio is listed in the acknowledgments to John Collier Indians of the Americas (Mentor Books, Washington DC, 1947) (along with Cohen, Nathan Margold, Harold Ickes and other people). Gamio is famous in Mexico as the excavator and restorer of the ancient city of Teotihuacan and as a public intellectual and supporter of the movement known as indigenismo ("indigenous-ism", or "Indianism"). On Gamio see David Brading "Manuel Gamio and Official Indigenismo in Mexico" (1988) 7 Bulletin of Latin American Research 75; Lucinda Gutiérrez and Gabrielo Pardo Descubridores del Pasado en Mesoamérica (Oceano, México D F, 2001); Benjamin Keen The Aztec Image in Western Thought (Rutgers University Press, New Brunswick (NJ), 1971) 470-71; Miguel León-Portilla "Historia de la Arqueología en México: La Época de la Revolución" (2002) 10 Arqueología Mexicana 10.

34 Collier Indians of the Americas, ibid. Collier also admired the great Brazilian Indianist and reformer Candido Rondon.

35 General Allotment Act 25 USC § 331-354 (Dawes Act). 
Collier openly admired Lázaro Cárdenas, president of Mexico from 1934-1940 and still today Mexico's most revered post-revolutionary president. ${ }^{36}$ The fact that a prominent United States government official and reformer could openly admire and esteem a Mexican radical politician like Cárdenas, who nationalised the ownership, production and distribution of petroleum and who was responsible for the return of vast areas of government lands to the indigenous communes under the ejido system is another illustration of the liberal and idealistic temper of American government under Roosevelt. For reasons that need not be explored here, following World War II United States policy entered a period characterised by support of authoritarian regimes in Central America and the Caribbean, the battle lines being regrettably hardened by events in Guatemala and Cuba in the 1950s. It is not coincidental that within the United States Federal Indian policy in the early 1950s also sharply reversed direction. The Indian New Deal and the work of Collier and his senior officials, including Cohen, had always faced congressional hostility. Following attacks by Western politicians on alleged favouritism to Western Indians as well as personal attacks on Collier himself, Collier resigned in 1945 and Indian policy was later placed in the hands of Dillon Myer - who had supervised the relocation of Japanese-Americans during the War. (Collier had been a prominent critic of Myer's methods.) In 1950 Myer embarked on a controversial policy of termination of tribal status and the phase of New Deal idealism in Federal Indian policy came to an end, to Cohen's great personal disappointment. ${ }^{37}$ Felix Cohen's article thus reflects not only a Spanish moment in Federal Indian law, but indeed a liberal and idealistic moment. The two are not, however, obvious partners.

36 Collier Indians of the Americas, above n 33, 96-97:

New revolutionary energy was the need. New passion, new vision, new administrative will. Lázaro Cárdenas supplied them. He became President at the end of 1934. In the six following years he established the agrarian revolution. He did very much besides. He established, once and for all, Mexico's national dominion over its natural resources, including oil. Working with the intellectually subtle, the brilliant, audacious Vicente Lombardo Toledano, he built organized labor into unity and power. Through millions - actually millions - of personal, face-to-face contacts with the Indians in every Mexican state, he built confidence and power into them. In 1940, though overwhelmingly the people's and the nation's choice, he refused to violate the constitutional clause against presidential self-succession; and he refused, and refuses still, to seek to dominate his successors from behind the scenes.

There has been no greater leader of any people in this age than Cárdenas; perhaps there has been none whose heart has been so rich and pure. Future time will possibly measure his achievement on behalf of the Indians as second only to that of Las Casas.

37 See Lawrence G Kelly "United States Indian Policies, 1900-1980" and Philleo Nash "Twentieth-Century United States Government Agencies" in Handbook of North American Indians: Vol 4: History of IndianWhite Relations (Smithsonian Institution, Washington, 1988) 66; 264. Cohen has left us in no doubt about how he felt personally about these changes in policy direction: see Felix S Cohen "The Erosion of Indian Rights, 1950-1953: A Case Study in Bureaucracy" (1952-1953) 62 Yale LJ 348. Most of Cohen's stinging criticism is aimed directly at Commissioner Myer. 
As noted above many writers today profess admiration and esteem for the $16^{\text {th }}$ century Spanish scholastics, often because they themselves belong to the naturalist camp and seek to develop a new understanding of international law reconstructed along naturalist lines. Collier, like Manuel Gamio, and like Cohen (as will be seen) greatly admired sixteenth century pro-Indian Spanish ecclesiastics such as Las Casas and Bishop Quiroga of Michoacan, but not at all from any kind of admiration for natural law, the Spanish empire, neo-Thomism, a desire to re-imagine the foundations of international law, or anything of the sort. Collier and Cohen were both passionate American leftwingers who, like their counterparts in Mexico, wanted to alleviate the shocking plight of the American Indians of the present day. Las Casas and Quiroga stood as early exemplars, as kinds of moral beacons; if they were to be appropriated to anything, it was to constructive reform and the ending of misconceived assimilationist policy. This seems to be a reading more worthwhile than many other tendentious modern reworkings of the Spanish legacy, although unfortunately it is probably no less unhistorical. In reality it is hard to see any direct historical legacy between Bishop Quiroga and President Cárdenas; but one feels that was not actually Collier's point in any case. He writes as an engaged and optimistic reformer, not essentially as a historian. This too is Felix Cohen's stance in some ways.

In the 1930s both Mexico and the United States pursued a similar anti-assimilationist path in indigenous policy, a major policy reversal for both countries, driven in both countries by progressive "indigenist" officials: principally Gamio in Mexico and Collier in the United States. As noted above, these two were friends who admired and respected one another. Collier always retained a hemispheric sense about indigenist policy, probably more than Cohen did. In the United States the main vehicle for new policies was IRA; in Mexico it was the ejido programme. Both had in common a rejection of earlier liberal models of individualising tenures - policies pursued in many countries, including New Zealand - and a return to automony and collectivist communal tenures. A repudiation of capitalistic individualism and a revalorisation of communal, if not "communist" tenures, places American and Mexican Indian policy of the day well on the left, exemplifying a kind of idealistic communalism which has had many antecedents in American and English radical history and which was to re-emerge in the idealistic environment of the new state of Israel after 1948 with its kibbutz movement.

\section{INDIANS AND WORLD WAR II}

Cohen's starting-point is disconcerting: he asks why it is that the American Indian peoples have been so willing to make an active contribution to the American war effort in the struggle against Germany and Japan. Probably most of us who pondered Cohen's question today would conclude that indigenous peoples - including American Indians and New Zealand Māori - were more than capable of perceiving Nazi Germany for what it was and as a menace to be actively confronted. But Cohen gives a different answer: the explanation for American Indian willingness to fight for 
democracy lies within the structures of American Indian law. To avoid unfair caricature it is best to let Cohen speak for himself: ${ }^{38}$

It may be doubted whether our tribal Indians are to be distinguished in physical strength or courage or health or pugnacity from native populations in some other parts of the world that have not rallied to the support of their governments in times of stress. At least the hypothesis is worth examining that what has distinguished our tribal Indians lies on a legal plane, that it is, in essence, a relation to government capable of evoking loyalty, and that in other parts of the world, where a similar relationship between peoples exists, as in the Philippines, a similar loyalty is likely to appear.

"What", Cohen asks, "is the nature of this legal pattern that has so dramatically shown its capacity to evoke loyalty"? 39

This may seem a strange way to begin an article on the Spanish legacy in Federal Indian law, but Cohen's article has to be seen in its historical context. At more or less the same time as Cohen's famous article, published in the dark days of mid-1942, Cohen's superior John Collier published a very similar piece on "The Indian in a Wartime Nation". Although I have no evidence to prove the point, it seems impossible to imagine that the publication of two such articles at more or less the same time by two of the most prominent Federal officials concerned in the management of Indian affairs was not part of a carefully coordinated strategy. Collier's article was published as part of a special number on "Minority Peoples in a Nation at War" in the Annals of the American Academy of Political and Social Science. ${ }^{40}$ In his article Collier, like Cohen, drew particular attention to the American Indian contribution to the American war effort. He mentioned Indian participation in the armed forces and in war industries, but also - significantly - stressed Indian participation in the war effort as an expression of tribal sovereignty. He mentioned the declaration of war of the Iroquois confederacy on the Axis powers (done in public at what some historians have seen as a somewhat stage-managed and contrived event at the Capitol in Washington DC in June 1942). ${ }^{41}$ Collier thus linked Indian participation in the war effort to the policy of restoration of tribal sovereignty that he, along with Felix Cohen, Nathan Margold and other officials had been pursuing since the enactment of IRA in 1934. The Iroquois declaration is certainly painted by Collier as a demonstration of tribal sovereignty. Like Cohen, Collier also links Indian sovereignty back to the Marshall decisions of the

38 Cohen "Spanish Origin", above n 1, 2-3.

39 Ibid, 3

40 John Collier "The Indian in a Wartime Nation" (1942) 223 Annals of the American Academy of Political and Social Science 29. Interestingly some Māori tribes in New Zealand also declared war on Nazi Germany.

41 Ibid, 34. See also Laurence M Hauptman The Iroquois Struggle for Survival: World War II to Red Power (Syracuse University Press, Syracuse (NY), 1986) 7-8. Hauptman described the Iroquois declaration as a "carefully orchestrated event, which never received endorsement by the full six Nations' leadership in council at Onondaga", ibid. 
$19^{\text {th }}$ century which he sees as establishing the basic concept that the Indian nations were "distinct independent political communities".

Seemingly Cohen's and Collier's articles were part of a coordinated political strategy to focus attention on Indian participation in the common struggle. Part of this may have been due to some short-term political events - in fact it seems that Indian draft evasion had been receiving a certain amount of publicity in the American media -but this was not, I suggest, all there was to it. Cohen and Collier were also seeking to emphasise the benefits to America of the highly controversial policies exemplied by IRA - abandonment of assimilation, the ending of allotment, and the restoration of tribal sovereignty. Collier particularly mentioned the need for continuation of the new policies after the war: a continuation of the programme of reacquistion of land on the reservations, expansion of Indian farming, and title improvement. More broadly, in the postwar era ways had to be found of "reconciling the rights of small groups of people to cultural independence with the necessity for larger economic units demanded by modern methods of production and distribution". ${ }^{42}$ It seems more than likely that both Collier's and Cohen's articles were aimed at IRA's proassimilationist opponents, who of course were able to wrest control of Indian policy out of Collier's hands after the war. One way of deflecting opposition to IRA was to stress its success in creating independent sovereign Indian communities who in the hour of crisis rallied to the defence of American democratic institutions by participating in the war effort. I do not criticise this as a strategy - in fact it strikes me as admirable in many respects - nor do I wish to contest it as misrepresentation of events. IRA, for all its faults, was definitely worth defending. And American Indians - like the Māori people of New Zealand - did indeed rally to the cause.

Collier does not mention a specifically "Spanish" legacy in his article, but his hemispheric approach to indigenous issues is certainly very clear. The war had created a strategic dimension to improving relationships with Latin America, as Collier notes, but additionally Collier wanted to see United States Indian policy become an example, or at least a reassurance, to Latin America. While, therefore, it may seem strange at first sight that Cohen begins his analysis with a discussion of American Indian participation in the global conflict, it is clear that this was no isolated discussion but reflected a common strategy involving John Collier and himself aimed at defending the gains made by Indian New Deal policies.

\section{CONCEPTUAL PARALLELS BETWEEN SPANISH AND FEDERAL INDIAN LAW}

As seen, Cohen begins his analysis with the matter of Indian participation in the war effort. He then moves from this point to identify what he sees as the four salient features of "existing Federal Indian law". These are the principles of "the legal equality of races", of "tribal self-government", of "Federal sovereignty in Indian affairs" and of "governmental protection of Indians". In focusing on

42 Collier "Indian in a Wartime Nation", above n 40, 35. 
these features, Cohen has to admit that in certain respects these principles still amounted to work in progress. Legislation making all American Indians citizens of the United States had in fact only been enacted as recently as 1924, and Indian voting rights at the time when Cohen wrote were still circumscribed by discriminatory state law in Washington, Arizona and New Mexico, three of the states with comparatively significant Indian minority populations. ${ }^{43}$ Cohen was on much firmer ground in seeing tribal self-government as a key feature of American law, a feature that distinguished the United States from other countries with indigenous populations (although Cohen does not pursue comparisons with, say, Canada or Australia, or come to that, anywhere). He derives the centrality of tribal self-government from Chief Justice Marshall's decision in Worcester $v$ Georgia $^{44}$ and from the decisions of the Supreme Court in Crow Dog and other cases. ${ }^{45}$ In Cohen's words: 46

Following this decision [Worcester] the federal courts have held that all Indian tribes have all the powers of self-government of any sovereignty except in so far as those powers have been modified or repealed by act of Congress or by treaty. Hence over large fields of criminal and civil law, and particularly over questions of tribal membership, inheritance, tribal taxation, tribal property, domestic relations, and the form of tribal government, the laws, customs and decisions of the proper tribal governing authorities have, to this day, the force of law.

In fact while the Marshall trilogy may well be said to recognise rights of tribal self-government, tribal self-government as developed United States policy was actually anything but a consistent plank of United States Indian policy. It was really a new policy, Cohen's and Collier's own. Cohen was writing his article at a time not only during a perilous period of World War II but also to support and justify IRA and associated policies of which he himself was a major architect. His article is less a historical analysis of American law as it had evolved in reality but rather an expression of what it might be at its best. Prior to IRA Federal Indian policy was avowedly assimilationist. Cohen's historical vision was essentially based on seeing the assimilationist policies pursued between the General Allotment Act and IRA as a kind of deviation from the true path of Indian tribal sovereignty as recognised in the Marshall trilogy of the early 19th century.

Assuming, however, for the sake of argument, that Cohen has indeed correctly identified the basic characteristics of Federal Indian law, in what way, precisely, are those characteristics in any meaningful sense "Spanish"? Cohen is aware that, given the pervasiveness of the leyenda negra in North American assumptions about Spanish colonial history, an emphasis on the Spanish juristic foundations of Federal Indian law in the United States will occasion a certain amount of scepticism.

43 Cohen "Spanish Origin", above n 1, 3 footnotes 2 and 3.

44 Worcester v Georgia (1832) 31 US 515 cited in ibid, 4.

45 Ex parte Crow Dog (1883) 109 US 556.

46 Cohen "Spanish Origin", above n 1, 4-5 (footnote omitted). 
Noting that in the Anglo-American world the Spanish treatment of the Indians of the Americas "has been so long held up to view as a pattern of cruelty and treachery" it will be considered "heretical" to claim "that the humane principles which guide our own law in Indian affairs all faithfully follow the teachings of Spanish theologians and the edicts of Spanish kings." ${ }^{47}$ While there was indeed an enormous amount of violence and cruelty in the conquests of New Spain and Peru the acts of the conquistadores were not an expression of the policy and opinions of the Spanish Crown and the Spanish Church: quite the reverse: 48

It would be childish to gloss over the inhumane aspects of the Spanish conquest of the New World. Yet there is an important difference between these aspects of the treatment of Indians in the New World in the fifteenth and sixteenth centuries and what Nazis have done in the Old World in the twentieth. Against the cruelties of the Spanish invaders the clear voice of protest was raised by loyal Spaniards and faithful Catholics to the King of Spain and to the Pope himself, and both King and Pope repeatedly denounced the acts of oppression committed by brigands that brooked no trans-oceanic control. So it is that while the acts of cruelty and treachery of lawless men wrought a havoc that eventually brought Spanish rule in the New World to an end, the legal ideals which Spanish teachers proclaimed, and which Crown and Holy See ratified, provided a humane and rational basis for an American law of Indian affairs.

The Spanish indeed did not always act like Nazis, and Cohen is quite right to note that there were was "a clear voice of protest". Cohen's argument is problematic nevertheless. In the first place it glosses over what is in fact a complicated and difficult question, that is, the relationship between the conquistadores and royal policy; not all specialists in Spanish colonial history would find this dichotomy between a well-intentioned "humane and rational" Crown and Church at the imperial centre and out-of-control cut-throat adventurers on the periphery very credible any longer. Matters were more complicated than that, although the complexities cannot be fully explicated here (many lengthy books have grappled with the issue). ${ }^{49}$ By making this point, of course, Cohen is having it both ways: even if the actual treatment of the indigenous peoples of the New World was founded on a regime of exploitation and oppression, as in fact it was, then Cohen can still say that these consequences did not reflect the real law and policy at the imperial centre. To which the rejoinder must be, any regime, including any colonial regime, must be evaluated as a whole, although it has to

47 Ibid, 9.

48 Ibid.

49 See for example Henry Kamen Spain's Road to Empire: The Making of a World Power, 1492-1763 (Allen Lane/Penguin Books, London, 2002); John Lynch Spain 1516-1598: From Nation State to World Empire (Blackwell, Oxford, 1991); Matthew Restall Seven Myths of the Spanish Conquest (Oxford University Press, New York, 2003); Hugh Thomas Rivers of Gold: The Rise of the Spanish Empire, from Columbus to Magellan (Weidenfeld and Nicolson, London, 2003). 
be admitted that in the case of a vast edifice like the Spanish colonial empire, which lasted for nearly three centuries, such evaluation is far from easy.

Cohen goes on to develop his argument by demonstrating that the four key features of Federal Indian law identified earlier also happen to characterise the Spanish colonial empire: legal equality, tribal self-government, central control of Indian affairs, and protection of Indian rights. ${ }^{50}$ In fact one could equally argue, I would say more persuasively, that the imperial Spain was characterised rather by legal, and, even more, by factual, inequality (although it is true that enslavement of the Indians was not permitted, at least in theory, in the dominions of the Spanish Crown); oppressive control and regulation of Indian communities in order to exploit Indian labour for the benefit of colonists; and finally a pervasive failure to protect Indian rights: virtually the opposite of everything Cohen says. ${ }^{51} \mathrm{He}$ was not wrong to stress the centralised control of Indian affairs, although this was often not strong enough to protect the Indians, and in any case the centre was no less interested in exploitation and appropriation of surpluses than were local elites. This still does not convey the full complexities of a vast and in many ways impressive imperial edifice that changed and developed over three hundred years, although it would be in my opinion - and that of many people - much nearer the truth. Rather than equality being subverted by local circumstances, it was more the other way round. The vice-royalties had no representative institutions of any kind, no parliaments or assemblies - unlike the British North American colonies - and no sense of equality before the law, or indeed any sense of a uniform law applicable to all. Rather "the Indies" was typified by a hierarchy of separate orders and jurisdictions, with different sets of laws applicable to each. "In New Spain", as Octavio Paz, the great Mexican writer and critic puts it, "the state, strongly centralised and with a powerful bureaucracy, protected particularism and privileged jurisdictions. ... The

50 Cohen "Spanish Origin", above n 1, 11-16.

51 Karen Spalding's classic study Huarochirí: An Andean Society under Inca and Spanish Rule (Stanford University Press, Stanford (CA), 1984) begins with the following affirmation: "[t]his book tells the story of a social relationship - a relationship of inequality and oppression - in a portion of the Andean highlands of Central Peru from before the European invasion of the sixteenth century to the end of the eighteenth century": ibid, 1. Spalding's book is a detailed case study of a particular Andean region which can nevertheless be fairly seen, I suggest, as representative. Cohen does not of course deny that there was a great deal of oppression; rather he argues that oppression was contrary to imperial law. This, I would argue, is partly wrong, and partly correct: certainly professions of racial equality can be found in some royal ordinances, but oppressive institutions such as the encomienda (labour grants to colonists) and the mita (compulsory labour in the mercury and silver mines in the Andes) were certainly provided for by legal ordinances emanating from the Crown. Another distinguished Andeanist, Steve Stern, has argued that the Indians of the altiplano, definitely a downtrodden, exploited and oppressed group, nevertheless had some limited freedom of manoeuvre to bring legal actions challenging the actions of Crown grantees and royal officials in the courts: see Steve J Stern Peru's Indian Peoples and the Challenge of Spanish Conquest: Huamanga to 1640 (2 ed, University of Wisconsin Press, Madison, 1993) especially 114-137. 
indigenous communities were governed by the laws of the Indies and each ethnic group had its particular status: Negroes, Mulattoes, Mestizos, Creoles and Spaniards." 52

With respect to the indigenous population the official policy was one of racial segregation with "Indians" and "Spaniards" confined to separate "republics" and being governed by separate laws, the Indians in the countryside and the "Spaniards" in the cities. In practice this separation proved impossible to maintain as Indians, blacks, Spaniards, mestizos and other groups ended up by mixing freely in such great cities as Lima, Potosí and Mexico City, in many trades and professions - Indians were able to practice nearly all oficios (trades) - and in workshops and the mines. ${ }^{53}$ The division of Mexico City into Spanish and Indian barrios (districts) did not last long. ${ }^{54}$ Racial groupings in New Spain and Peru broke down or became blurred. There were many blacks in the vice-royalties, some slaves but free blacks as well, and a growing mestizo (mixed-race) population who failed to fit into any clear legal categories. But this arose not from formal legal equality but rather from an inability to realise in practice a segregationist system of law based on caste, privilege, and multiple jurisdictions.

I do not intend here to construct a countervailing picture of the Spanish colonial empire to that advanced by Cohen; surely it is enough to say that both his presentation of the foundations of Federal Indian law and the position of the Indian communities in, say, the vice-royalties of New Spain and Peru are both roseate in the extreme and gloss over vast complexities. One can note the thoughts of a leading Early Modernist and historian of the Spanish empire, Henry Kamen, and then move on. To Kamen the key reality is that what was said, done and thought in the lecture halls at Salamanca made next to no impression on the actual administration of the Spanish colonial empire in reality: ${ }^{55}$

The concern of the Dominican professors at Salamanca university about property rights, a concern shared by many Renaissance intellectuals including Charles V, made them develop a number of ideas that have since been accepted as a pioneering contribution to the theory of international law. Their highly important work, transmitted in part through the well-known labours of Las Casas has too often been configured in a way that stands on its head the solemn reality of what took place in the period of

52 Octavio Paz Sor Juana: Las Trampas de la Fe (Fondo de Cultura Económica, México D F 1982) 33:

En Nueva España sucedió algo muy distinto: el Estado, fuertamente centralizado y con una burocracia poderosa, protegió los particularismos y las jurisdicciones privilegiadas. Las communidades indígenas estaban regidas por las leyes de Indias y había estatutos especiales para los diferentes grupos étnicos: negros, mulatos, mestizos, criollos y españoles.

53 For a richly illustrated discussion of this "impossible segregation" see especially Bernard and Gruzinski Los mestizajes, above n 23, 230-294.

54 See ibid, 270: La división de la ciudad de México en un centro español y una periferia india formada por barrios indígenas también se frustró.

55 Kamen Spain's Road to Empire, above n 49, 492. 
empire. A number of professors, missionaries and administrators were indeed concerned to make Spanish imperialism function according to ethical and European rules. But the "theory of empire", even though it served to guide legislators (such as Philip II in his Ordinance of 1573), had small influence on the real world. The different views over property had little effect on practical politics, for they did not touch or alter the basic conviction that the empire existed in order to make a profit. The inherent property rights of a black man, for example, were recognized and often respected, but did not modify the institution of black slavery. When slavery was essential to make the business prosper, it was used. Throughout Spanish America, slavery of the native Indian through the institution known as the encomienda continued to be practised long after it had been theoretically abolished. In the same way the notion that the supra-national empire should be rationally organized in economic terms, was constantly undermined by the essentially predatory policies of the central government in Madrid.

Kamen's opinions about the empire are controversial in Spain, as Kamen has found, but are less likely to be so in Latin America: few Mexican, Peruvian, or Chilean scholars are under any illusions as to the nature of the Spanish colonial empire or the consequences of its long history for their own countries. ${ }^{56}$ Rather than develop any further a historical argument that the reality of the Spanish colonial empire was somewhat different and vastly more complex than the picture presented by Cohen, which I suggest can be taken as read, it seems more interesting and valuable to focus now on the third dimension of Cohen's argument, that is the "actual connections" between Spanish law and Federal Indian law.

\section{ACTUAL LINKS BETWEEN SPANISH AND FEDERAL INDIAN LAW}

\section{A Introduction}

Cohen wishes to point to not just structural similarities between Spanish imperial law and Federal Indian law at their best, but rather to draw attention to direct historical connections between the two. It is this that gives a particular interest and fascination to his work. How, though, as a matter of the historical record, did $A$, Spanish imperial law, impact on $B$, Federal Indian law, in the United States? Cohen believes that it "can be shown that the similarities of principle ... were not

56 The vast literature in Spanish can hardly be summarised here, but some representative books are Jan de Vos La Paz de Dios y del Rey: La conquista de la selva Lacandona (1521-1821) (Fondo de Cultura Económica, México D F, 1980); Antonio García de León Resistencia y Utopía: Memorial de Agravios y Cronicas de Revueltas y Profecias Acaecidas en la Provincia de Chiapas Durante los Ultimos Quinientos Anos de su Historia (Ediciones Era, México D F, 1981); Juan José Vega Los Incas Frente a España: Las Guerras de la Resistencia (Peisa, Lima (Peru), 1992); Silvia Soriano Hernández Lucha y Resistencia en el México Colonial (Universidad Nacional Autonoma de Mexico, México D F, 1994); Gabriela Solís Robleda Entre la tierra y el Cielo: Religión y Sociedad en los Pueblos Mayas de Yucatán Colonial (Porrúa, México D F, 2005); José Bengoa Historia de los Antiguos Mapuches del sur (Catalonia, Santiago (Chile), 2007). All these books deal specifically with various forms of indigenous resistance to the Spanish during the colonial period. A full historiographical discussion is beyond the scope of this article. The literature in Spanish on the colonial Spanish empire not surprisingly dwarfs the substantial literature in English; not much of the Spanish literature gets translated. 
fortuitous ... but were rather the result of definite Spanish influences which molded the development of legal doctrine in the United States". ${ }^{57}$ This influence came about in three different ways: through the development of international law and its reception by the United States Supreme Court in key cases dealing with Indian rights; by means of treaties by which the United States agreed to respect property rights and the protections of Spanish law; and thirdly, by means of the actions of the Indians themselves. Each of these is a very interesting claim meriting close examination.

\section{B Spanish Law Operating through International Law: the Legacy of James Brown Scott}

Cohen argues, first, that the Spanish legacy had entered American law through international law, which in turn originated from the Spanish jurists: "our Indian law originated, and can still be most clearly grasped, as a branch of international law", and in the area of international law "the basic concepts of modern doctrine were all hammered out by the Spanish theological jurists of the sixteenth and seventeenth centuries". ${ }^{58}$ Of particular importance here is - of course - Francisco de Vítoria, acclaimed, notes Cohen, at the Seventh Pan-American Conference (1933) as one who "established the foundations of modern international law". 59

Significantly Cohen here cites the prominent American international lawyer James Brown Scott as an authority on the Spanish foundations of international law. In fact Cohen's article can be seen as an extension of a juristic project commenced originally by Scott: Cohen extends to Federal Indian law a revalorisation of the Spanish contribution to modern legal history begun first by Scott in the field of international law. Professor Scott was the most ardent champion of Vítoria in the world of Anglo-American legal scholarship. The title of his famous book says it all: The Spanish Origin of International Law: Francisco de Vitoria and his Law of Nations, ${ }^{60}$ published with the support of the Carnegie Endowment for International Peace in 1934 ("of the capacity of Vitoria as an international

57 Cohen "Spanish Origin", above n 1, 17 (emphasis added).

58 Ibid.

59 Ibid.

60 James Brown Scott The Spanish Origin of International Law: Francisco de Vítoria and his Law of Nations (Clarendon Press, Oxford, and Humphrey Milford, London, 1934) [Scott Spanish Origin]. Scott had very close links with Spain and Latin America. He wrote a number of articles relating to international relations between the United States and the Latin American Republics (see for example Scott "The Treaty between Colombia and the United States" (1921) 15 Am J Int'l L 430). Scott was also involved with the establishment of the Asociación Francisco de Vítoria in Spain in 1928: see Scott "Asociación Francisco de Vítoria" (1928) 22 Am J Int'l L 136. The establishment of the association followed a conference held at Salamanca in 1926, "a celebration", Scott writes, "of the four hundredth anniversary of Francisco de Vitoria's appointment to the chair of theology in the University of Salamanca, from which he gave, for the first time, an acceptable definition of international law and of its sources, and professed its principles applied to the concrete facts of international life", ibid, 137. 
lawyer this volume is at once a testimony and an act of homage"). ${ }^{61}$ Scott's work was well-known and very influential. It will therefore have seemed natural to Cohen to extend Vítoria's legacy into the area of Federal Indian law given that the status of the native peoples of the New World was a central focus of what remains today of the content of Vitoria's lectures at Salamanca. Scott's work would have helped create a situation in which making the leap from international to Federal Indian law would in fact have seemed obvious.

Scott's work has itself now become a focus of criticism. He has, for instance, been accused of presenting a naïvely celebratory and "de-historicized" picture of Vítoria in a recent article by Fernando Gomez. ${ }^{62}$ After citing some of Scott's more startlingly anachronistic passages in Spanish Origin where Vítoria is praised as a "liberal-minded Dominican", a "moralist", and even as "a liberal", Gomez proceeds: ${ }^{63}$

These quotes give us a sufficient taste of Scott's incongrous rhetoric. These virulent anachronisms exemplify a rather genuine example of the blocked historical imagination of the affluent society by the mid twentieth century. Scott's prose will give no handles to the reader. Its almost unbearable lightness of being will give the attentive reader no rest. There is nothing other than this supposedly irresistible atemporal collection of marvelous things in no specific time or place. There is no pain in this universal history. Nothing appears to hurt Scott. The anachronism, at least in my mind, of attributing the "goodness" of a pluralist vision to a sixteenth-century theologico-legal thinking should need no further elaboration.

One feels that this is to go a bit far (why "virulent" anachronisms?). Scott's enthusiasm for Vítoria seems to have been a benign affliction, seeking only to give additional moral force to international law in the darkening world scene of the late 1920s and 1930s. In 1926 courteous and gentlemanly scholars from Germany, Spain, the Netherlands, and the United States were still able to meet in Salamanca to discuss international law and the great Vítoria and plan an association in his memory with the outbreak of the Spanish Civil War less than a decade away. One problem is that Scott's enthusiastic way of writing has simply gone out of fashion. Nevertheless Gomez has a point. Scott's remorselessly celebratory tone, highly coloured style, uncritical approach, tendencies to romanticism and anachronistic terminology - he really does refer to Vítoria as a "liberal", an odd term to apply to a $16^{\text {th }}$ century Dominican theologian who was invited by his government to be part of the Spanish team at the Council of Trent - makes his work difficult reading nowadays.

Although naturalist writers continue to bracket Las Casas and Vítoria together and extol them, along with Suárez, as founding fathers of international law, other scholars of international law

61 Scott Spanish Origin, ibid, 69.

62 Fernando Gomez "Francisco de Vitoria in 1934, Before and After" (2002) 177 Modern Language Notes 365.

63 Ibid, 385. 
writing today now tend to reject this. It has become controversial to see Vítoria and his followers as the founders in any meaningful sense of modern international law. This is a claim that mainstream Renaissance historians have long been dubious about, in particular Garret Mattingly, author of a famous book on Renaissance diplomacy published in 1955. ${ }^{64}$ Mattingly, also American, had great difficulty in seeing anything modern in the writings of Vitoria and others of the Spanish school, given that "most of the conclusions at which the Spanish school arrived are obviously implicit in twelfth-century canonists with explicit elaborations in the fourteenth and fifteenth centuries". ${ }^{65}$ Vítoria wrote and thought against a background of "accepted ethical principles", those which had formed the basis of the teaching of philosophy and theology in the European universities for centuries, "and this", as Mattingly emphasises, "at a time when the moral consensus of Europe was less secure than it had been for centuries, and was being weakened further by the passage of every decade". ${ }^{66}$ Mattingly is here, of course, referring to the outbreak of the Reformation in Germany, in many ways a direct assault on the entire intellectual edifice to which Vítoria and scores of other academics belonged. ${ }^{67}$ In fact far too much is written and apparently believed about the Spanish scholastics, especially by Catholic and naturalist commentators, that seems strangely remote from the reality of the confessional strife which was engulfing Europe during the lifetimes of Vítoria and the other Spanish "fathers": it is possible that Vítoria may not have had much awareness of confessional strife in Europe, then in its earlier phases and perhaps destined to disappear; but to discuss (say) Suárez without siting him in his context of religious conflict in Europe, as many do, is completely unhistorical.

International lawyers writing in the present day stress if anything the pre-modernity of the Spanish school, especially David Kennedy, who in an influential long essay published in the Harvard Journal of International Law in 1986 grouped Vítoria with Suárez, Gentili and Grotius as

64 Garrett Mattingly Renaissance Diplomacy (Penguin Books/Jonathan Cape, London, 1955). Mattingly was professor of European history at Columbia from 1948-1962. At least one scholar has misinterpreted Mattingly as to be arguing that the origins of international law should be pushed back to Aquinas! This, as far as I can see, is not his meaning at all: rather, he is rejecting the suggestion that international law in any modern sense was a concern of Vítoria's: compare Muldoon "Canonistic Contribution", above n 5, 265-266.

65 Mattingly Renaissance Diplomacy, ibid, 270.

66 Ibid, 278.

67 For a brilliant assessment of the challenge posed by Lutheran and Calvinist thought to scholastic philosophy and theology see Peter Harrison "Philosophy and the crisis of religion" in James Hankins (ed) The Cambridge Companion to Renaissance Philosophy (Cambridge University Press, Cambridge, 2007) 234249. Luther was completely hostile to the Aristotelianism of the universities and of course stood for the proposition that "the issues at hand were not to be determined on the basis of ecclesiastical authority - the pope or a Church council - but instead by appeals to Scripture as understood by the individual" (the Lutheran principle of sola scriptura): ibid 236. Vítoria, however, works entirely within the AristotelianThomist-Canonist framework. 
representative of the phase of "primitive legal scholarship" of international law. ${ }^{68}$ Kennedy's reading of Vítoria and Suárez has been followed and developed by Martii Koskenniemi, ${ }^{69}$ a leading contemporary international law theorist and historian of international law jurisprudence. Neither Kennedy nor Koskenniemi feel able to see the development of contemporary international law as developing in any kind of linear way from Vítoria and his followers. As Kennedy puts it: ${ }^{70}$

The tone, method and doctrinal argument of these texts suggest that primitive legal scholars addressed international problems similar to those treated by later scholars, but in a fashion so dissimilar from later work that historians who focus on the primitives' role as "founders" of modern international law, distort the primitive texts' opposition to modernity.

To Kennedy, what is most striking about "primitive" international legal scholarship is the complete absence of differentiation between normative rules: scripture, passages from Aristotle, papal bulls and decretals and the remarks of the Church fathers are all cited, as it were, in the same breath as illustrative of a universal moral-legal order which is binding on everyone and everywhere. Kennedy sees in Vítoria a "conflation" of morality and law. It is not that Vítoria develops a moral or ethic critique of "law"; rather any distinction between law and morality is simply meaningless to him. Vítoria "does not suggest any rule which is morally but not legally binding". ${ }^{71}$ Thus Vítoria's treatise De Indis begins quite unselfconsciously with a passage from St Matthew's gospel, chosen not as illustrative or to make a theological point but rather as simply normative. ${ }^{72}$ In Kennedy's words: ${ }^{73}$

In fact, Vítoria's texts contain no explicit or implicit distinction of the binding power of the moral or divine and legal orders. Distinctions made in the shorter conceptual works turn out to be fundamentally different from the separation of moral and legal obligation with which later theorists are familiar. For example, although they distinguish ecclesiastic and civil power, spiritual and temporal authority, and mortal and venial sin, Vítoria does not imagine a human law whose binding force arises other than from divinely ordained morality or which binds in action but not in conscience. Vítoria does not "argue" that sovereigns can not disagree about such things, he assumes it.

68 David Kennedy "Primitive Legal Scholarship" (1986) 27 Harv Int'l LJ. (No doubt many contemporary Grotians would bristle at their hero being classed as a "primitive".

69 Martti Koskenniemi From Apology to Utopia: The Structure of International Legal Argument (Reissue with New Epilogue, Cambridge University Press, Cambridge, 2005) 95-106. Koskenniemi basically follows Kennedy's analysis of Vítoria and the other "primitives".

70 Kennedy, above n 68, 5.

71 Ibid, 17.

72 See ibid, 15.

73 Ibid, 16 (emphasis added). 
Therefore there can be no recognition of any kind of cultural relativism in Vítoria's work, nor can there be any suggestion that the Indians of the New World might possess independently valid norms of their own. How they should be treated and understood is set entirely within a Catholic and Aristotelian intellectual framework that Vitoria treats as universally binding. In strong contrast with later theories of international law, sovereign states do not in any sense create international law arising out of their custom and practice inter se. If the behaviour of states is in accordance with universal norms such behaviour merely illustrates such norms; state behaviour which violates such norms constitutes nothing whatever. ${ }^{74}$ Vítoria's world-view predates concepts of "sovereignty" in any event. Thus, to Kennedy and Koskenniemi, Vítoria and the other "primitives" are locked within a pre-modern normative framework which makes it impossible to see them as "founders" of international law in any real sense.

The other principal post-Cohen critique that has emerged of Vitoria comes from Robert Williams, who has set out to deconstruct the entire edifice of Federal Indian law and indeed the whole conceptual structure of native title law. While Kennedy and Koskenniemi deny any direct continuity between Vítoria and other primitives and modern international law theory, Williams advances a radically different argument. In fact Williams agrees with Cohen in seeing Vítoria's legacy as powerful, but disagrees with Cohen as to the nature of this legacy. While Cohen sees Vítoria's legacy positively, Williams sees it negatively: as a cornerstone of a fundamentally "racist" edifice which forms part of a "totalizing" discourse which refuses to accept that indigenous peoples had norms and state systems of their own. ${ }^{75}$ Up to a point Williams' and Kennedy's analysis of Vítoria coincide in that both see his thought as universalising with no space left for a relativistic assessment of non-European modes of thought and systems of government. Where Kennedy and Williams diverge is that Williams does not see Vítoria as an exemplar of "primitive" international legal scholarship. Instead Williams sees Vítoria as essentially modernising Spanish claims to sovereignty in the New World. To Williams, Vítoria shifts Spanish claims to sovereignty from medieval foundations based on papal grants to a new Renaissance foundation based on Indian violations of general norms relating to the rights of all Christian states to trade and preach the

74 See Koskenniemi, above n 69, 98-9: "A consensus gentium, or custom, may be evidence of rules (just as it may be evidence of God's existence) but [to Vítoria] it has no independent binding authority. It is not law simply by being a consensus".

75 A similar critique is developed by Anthony Anghie in his article "Francisco de Vitoria and the Colonial Origins of International Law" (1996) 5 Social and Legal Studies 321. Anghie in a sense links Kennedy's focus on Vítoria's universalism with Williams' critical reading of Vítoria as an apologist to see the latter as creating a set of "universally applicable norms" to which colonial peoples have no option but to conform. That is, Vítoria's universalism is seen neutrally by Kennedy but critically by Anghie. To Anghie "Vitoria's real importance lies in his developing a set of concepts and constructing a set of arguments which have been continuously used by western powers in their suppression of the non-western world and which are still regularly employed in contemporary international relations in the supposedly post-imperial world": ibid, 332. 
Christian faith. ${ }^{76}$ Vítoria did this, Williams implies, specifically in order to rest Spanish claims to dominium in the New World on more secure foundations given that the claims to the universal jurisdiction of the papacy were coming under challenge in Renaissance Europe. To Williams, Vítoria "was the first articulator of a European discourse of conquest founded on secularly rationalizable norms and values". ${ }^{77}$ This discourse, however, was "no less totalizing and hierarchical in its outlook than the medieval response to radical difference". ${ }^{78}$ Professor Scott's Vitoria and that of Professor Williams could not be more different: to one he is the heroic founder of international law, to the other a loyal servant of the Spanish Crown who helpfully devised an updated method of claiming sovereignty in the New World.

Williams' analysis overlooks the fact that Spain never did discard claims to sovereignty in the Americas based on papal grant; this actually remained the principal justification for Spanish territorial claims. The theory of papal grant had the virtues of simplicity and clarity as far as the Spanish Crown was concerned. The doctrine of terra nullius never entered the framework of Spanish colonial law as there was no need for it to do so. As J H Elliott emphasises, "[i]n claiming sovereignty ... the Spaniards, unlike the English, had little or no need of the doctrine of res nullius, since their title was based on the original papal cession to the Spanish [C]rown". ${ }^{79}$ The papacy remained a natural reference for Spaniards and Spanish Americans in matters of international law for centuries. In fact even as late as 1906 the republics of Peru and Colombia can be found submitting a border dispute between them to mediation by Pope Pius X. ${ }^{80}$ Williams thus certainly exaggerates the significance of Vítoria's repudiation of the papal grants: if his true significance lies in a modernisation of Spain's claims to title in the New World it seems strange that the Crown never took much note of it. Nevertheless Williams' critique is undoubtedly the most important revisionist analysis of Vítoria and the Salamanca school to date, and his analysis of Vítoria seems convincing in many respects. To put the position in a moderate way, those who see Vítoria and his successors as founding fathers of international law and the law relating to indigenous peoples must reckon with Williams' powerful critique which, on the contrary, sees him as a founder of body of thought which denies indigenous forms of political organisation any kind of recognition. That Vítoria's thought is "totalizing" is something that David Kennedy would presumably not dispute, even if he might not quite put it that way.

76 See Robert A Williams The American Indian in Western Legal Thought: The Discourses of Conquest (Oxford University Press, New York, 1990) 103.

77 Ibid, 106.

78 Ibid, 107.

79 Elliott Empires of the Atlantic World, above n 12, 30.

80 See John Hemming Tree of Rivers: The Story of the Amazon (Thames and Hudson, London, 2008) 204-5. 
Yet another perspective on Vítoria comes from certain scholars who see him as less concerned to explore legal solutions to the questions posed by Spanish claims to sovereignty in the New World than to develop certain theological positions that arose out of the conflicts between the papacy and the conciliar movement within Catholicism during the $15^{\text {th }}$ century. This view is essentially to see Vítoria as preoccupied by certain legal-theological issues of his day which he analysed and explored by using the legal challenges posed by Spanish imperial expansion as a case study. This stance is not dissimilar from Kennedy's, although it is to place more emphasis on theological and philosophical debate within late-medieval Catholicism. ${ }^{81}$ Vítoria's real interest and concern may have been primarily with questions of theology and canon law and only secondarily with the Americas. I believe this was in fact the case, although this is not the place to pursue the argument. Suffice it to be said that as far as the Crown was concerned Vitoria was perceived essentially as a brilliant theologian of such unimpeachable orthodoxy and reliability in the Crown's interests that he was invited by his government to represent Spain at the Council of Trent. (Vítoria declined on the grounds of age and poor health). ${ }^{82} \mathrm{He}$ would not have been asked if his religious orthodoxy was suspect in any way.

These different critiques therefore do mean that Cohen's argument that via "Spanish"-created international law a humanist and pro-Indian stance flowed into American law calls for some rethinking. Essentially the three perspectives I have outlined seek to clarify what Vitoria and his contemporaries were seeking to do, and their combined effect now makes it difficult to see Vítoria in any straightforward way as a "founding father" of international law and thus (pace Cohen) of indigenous people's law. Another aspect of Cohen's argument that has become problematic is, in fact, the "Marshall trilogy" itself, concerning which a rich historiography and body of legal writing has developed in the years since Cohen wrote his famous paper. ${ }^{83}$ While the decisions are regularly cited, along with Cohen's article, in practically every Federal Indian law article that gets published in the United States - as well as plenty that get published in other countries, including this one - it has now become impossible to see Marshall's decisions, I suggest, through Cohen's eyes. To Cohen, and, as we have seen, to John Collier, the Marshall decisions stand as an uncomplicated recognition of American Indian sovereignty. Not many legal historians would give that reading a straight

81 See Katherine Elliott van Liere "Vitoria, Cajetan and the Conciliarists" [1997] Journal of the History of Ideas 597 and references therein cited.

82 See Scott Spanish Origin, above n 60, 86-7 where the King's letter and Vítoria's very courteous reply are reprinted.

83 The three decisions in the trilogy are Johnson $v$ M'Intosh (1823) 21 US 543; Cherokee Nation $v$ Nation (1831) 30 US 1; Worcester $v$ Georgia, above $n$ 44. On the legal significance of the cases see especially Howard Berman "The Concept of Aboriginal Rights in the Early Legal History of the United States" (19771978) 27 Buffalo Law Review 647. The best historical studies of the context of the cases in my opinion are two books by William G McLoughlin, a specialist in Cherokee history: Cherokee Renaissance in the New Republic (Princeton University Press, Princeton, 1986); Cherokees and Missionaries, 1789-1839 (University of Oklahoma Press, Norman and London, 1995). 
endorsement these days, and there are a few who would strongly disagree. ${ }^{84}$ Other scholars accept that while international law did influence Chief Justice Marshall, and that this body of law was at least partly shaped by Vítoria and other Spanish teachers, this body of international law if anything influenced Marshall into taking a "narrow and paternalistic" view of the stance of Indian nations, at least in Johnson $v$ M'Intosh; ${ }^{85}$ yet others contend that to the extent that Marshall was influenced by Spanish law he misapplied it. ${ }^{86}$ Also the actual history of Indian removal, the direct context for two out of the three decisions, is not only better understood but has moved to centre stage in the historiography of Jacksonian America. Whatever the doctrinal content of the three Supreme Court cases, it is certainly clear that the decisions were of no benefit to the Cherokees themselves; they were certainly removed in any case. ${ }^{87}$

What remains of Cohen's suggestion that "Spanish" legal ideas have come to underpin Federal Indian law by means of Marshall J's utilisation of international law in the famous "trilogy"? Obviously there are some difficulties with this. Some important scholars in international law theory see the differences between modern international law ideas and the Spanish school as far more important than the links between them. This however is not a viewpoint that all share no doubt international law writers of a more naturalist standpoint will continue to see Vítoria and Suárez as progenitors of their particular vision of what international law should be, and it is hard to see that they would be wrong to do so. It can be said that the naïvely celebratory stance towards Vítoria taken by Professor Scott strikes a modern reader as tendentious and unconvincing, but it does not

84 See for example Joseph C Burke "The Cherokee Cases: A Study in Law, Politics and Morality" (1968-1969) 21 Stan L Rev 500, 531: "[t]he Marshall Court was moved by politics and morality in the Cherokee cases but it moved no further than the law allowed"; Christine A Klein "Treaties of Conquest: Property Rights, Indian Treaties, and the Treaty of Guadalupe Hidalgo" (1996) 26 NM L Rev 202, 206: "Justice Marshall's discourse, although eloquent and politically expedient, sanctioned the conquest of Indian lands".

85 Johnson v M'Intosh (1823) 21 US 543.

86 So I understand James J Lengel to be arguing in his "The Role of International Law in the Development of Constitutional Jurisprudence: The Marshall Court and American Indians" (1999) 43 American Journal of Legal History 117. Lengel certainly accepts that "[t]he search for applicable principles of law to provide a basis for constitutional doctrine involved the reception and application of international law to problems raised in several cases decided by the Supreme Court in the early 1830s": ibid, 117. Another important discussion is Ali Friedburg "Reconsidering the Doctrine of Discovery: Spanish Land Acquisition in Mexico" (1999) 17 Wisconsin Law Journal 87 (arguing that Marshall misunderstood Spanish law and misapplied it in Johnson to legitimise a right to claim title by "discovery" which in fact Vítoria does not recognise). Freidburg sees Johnson as "a departure from international precedent and its humanistic foundations". This is to gloss over a great deal as well.

87 I do not of course mean to suggest that Felix Cohen was unaware of the details of the tragic history of the Cherokees, and of course the doctrinal content of the cases still stands, irrespective of the actual behaviour of Andrew Jackson and the government of the state of Georgia. The point is more that the political complexities of the time, especially the nullification crisis and the drift towards sectional politics in the United States, may well have impacted on the actual content of the decisions in ways that Cohen may not have appreciated. 
necessarily follow that one has to accept that Robert Williams and like-minded writers have captured the whole reality with regard to Vitoria either. A key problem that all have to accept with Vítoria is how little we really know about him. Why was he so famous, and why did students flock to his classes - as they evidently did? Maybe it was just that he was a brilliant teacher and was worth listening to. Maybe it had to do more with the intellectual context of the times and the excitement inspired by a renewed and revitalised Aristotelianism emanating from the University of Paris, where Vítoria studied and taught before coming home to Spain. But maybe many in Spain really were genuinely troubled and fascinated by the legal problems posed by the conquest and settlement of the Americas. Spain did at least have a debate, which no other colonial powers did. But seeing a direct link between this process of debate, Marshall's decision, and American Indian law today in the United States is not easy. The best that can be said, in my view, is that Marshall's decisions to some extent created Federal Indian law, that Marshall's reasoning and analysis was influenced to some extent by international law, and that Vítoria and the other great Spanish writers and thinkers of the Renaissance to some extent influenced the development of international law.

\section{Spanish and Mexican Land Grants and United States Federal Indian Law}

Cohen suggests that a second important concrete source of the Spanish underpinnings of Federal Indian law came about as a consequence of formal recognition "in treaties by which the United States undertook to recognise property and other rights enjoyed by the inhabitants under the former sovereign". ${ }^{88}$ This seems to be essentially the same notion that Cohen puts forward as a separate mode of reception: the fact that United States courts determining property rights in those parts of the United States that were formerly under Spanish dominion must sometimes have to take account of Spanish law. While much of the United States was formerly - at least in a nominal sense - part of the dominions of the Spanish Crown, it appears that only with those areas where there was a specific promise to respect Spanish and Mexican property rights that the former law has in actuality become a significant issue for the courts of the United States.

In particular Cohen cites the Treaty of Guadalupe Hidalgo (1848), this being the fairly notorious treaty - notorious, certainly, to Mexicans - by which Mexico was forced to cede nearly half of her national territory to the United States following the latter's victory in the Mexican-American war. ${ }^{89}$ Guadalupe Hidalgo is generally regarded as one of the harshest and most punitive treaties in modern history. ${ }^{90}$ The treaty did however recognise the property rights of Mexican nationals who now found themselves within the borders of the United States. These property rights included land grants

88 Cohen "Spanish Origin", above n 1, 18.

89 Treaty of Peace, Friendship, Limits and Settlement (2 February 1848) 9 Stat 922. On the negotiations over the Treaty provisions relating to Spanish and Mexican property rights see especially J J Bowden "Spanish and Mexican Land Grants in the Southwest" (1973) 8 Land and Water Law Review 467.

90 See generally Christine A Klein "Treaties of Conquest: Property Rights, Indian Treaties, and the Treaty of Guadalupe Hidalgo" (1996) 26 NM L Rev 201, 208-9. 
made by the Crown or the Republic of Mexico after independence in 1821 not only to Hispanic Mexicans, but also to Mexican Indians, especially the Pueblos of New Mexico and Arizona. ${ }^{91}$ As Cohen points out, the relevant clauses in the Treaty of Guadalupe Hidalgo meant that United States courts had to grapple with questions of Spanish and Mexican property law. It was a precondition for recognition of pre-annexation property rights that the rights claimed must originally had to have been validly granted under the preceding legal regime. The pre-existing Spanish and Mexican law happened to be very intricate, as it was founded not simply on property law concepts deriving from Castilian law but also on Spanish and Mexican ordinances and statutes as well.

The reality that lies behind Cohen's analysis is however a very complex and embittered one, which can fairly be said to be a long history of broken promises and frustration for the grantees and their descendants. Problems with defective titles have turned out to be "a curse and a plague in the Southwest ever since the United States acquired the area from Mexico". ${ }^{92}$ Intricate cases dealing with the old grants are even now still being fought out in the United States courts 160 years after Guadalupe Hidalgo was signed. ${ }^{93}$ Violent confrontations between lumber barons and ranchers or government authorities on the one hand and the descendants of the Spanish/Mexican grantees on the other, who are usually poor rural people, have occurred from time to time. ${ }^{94}$ A substantial literature has developed on the grants - not, however, anything like on the same scale as the literature on Federal Indian law - some of it written by rather angry younger Mexican-American legal scholars who no doubt would regard Cohen's picture of the old grants as being a means by which Spanish legal ideas penetrated Federal Indian law as nothing less than a joke. ${ }^{95}$ But it is not only radical Mexican-American scholars who now deplore the treatment meted out to former Mexican citizens

91 Cohen in fact was extremely knowledgeable about the involved complexities related to Pueblo land and water rights - sourced in Spanish and Mexican law - in the law of the United States, to which he devoted an entire chapter of his Handbook: see Handbook, above n 27, ch 20. "[I]n order to understand the present legal status of these Pueblos" it is necessary, Cohen writes, "to allude to certain basic principles developed prior to the acquisition of New Mexico by the United States", ibid, 383.

92 Bowden, above n 89, 511.

93 See for example Gregory A Hicks "Memory and Pluralism on a Property Law Frontier: The Contested Landscape of New Mexico's Costilla Valley" (2005) 47 American Journal of Legal History 383; Lobato v Taylor (2002) 71 P 3d 938 (Co); (2003) 70 P 3d 1152 (Co) cited in ibid, 409; Robert V Urias "The Tierra Amarilla Grant, Reies Tijerina and the Courthouse Raid" (1995) 16 Chicano-Latino Law Review 141.

94 See Placido Gomez (Comment) "The History and Adjudication of the Common Lands of Spanish and Mexican Land Grants" (1985) 25 Natural Resources Law Journal 1039.

95 This may seem a bit harsh, but see for example Guadalupe T Luna "'This Land Belongs to Me': Chicanas, Land Grant Adjudication, and The Treaty of Guadalupe Hidalgo" (1999) 3 Harvard Latino Law Review 115 (the author refers to "a shameful legacy of dubious and imprecise rulings through which the government protected homesteaders and squatters, enlarged the public domain for its own purposes, and 'legally' disempowered Chicanas", ibid, 159; the case law "unmasks the unequal treatment imposed on the Chicana and the impact of biased and inconsistent rulings", ibid). See also Vicki Ruiz "Nuestra America: Latino History as United States History" (2006) 23 Journal of American History 655. 
in the United States after Guadalupe Hidalgo: in fact a particularly critical interpretation is found in the most recent volume of the august Oxford History of the United States. ${ }^{96}$

The property rights of former Mexican citizens living in various states of the Union were subject to state legislation, some of which was little less than punitive. One example is the California Land Settlement Act 1851, which imposed a two-year limitation period on all Spanish/Mexican land claims, leading in turn to much litigation in the California state courts. Similar complexities developed in New Mexico, Colorado, Arizona, Texas and Florida, all states where the old grants are still a political and legal issue of continuing importance. The history of the grants in United States law is - to put it neutrally - controversial. In New Mexico, for example, the Court of Private Land Claims, which inquired into the grants from 1891-1904 and which rejected about 94 per cent of the claimed acreage, added a vast area of some 30,000,000 million acres of land to the public domain lands of the United States. ${ }^{97}$ Cases became bogged down in the courts. One case became "reportedly the oldest active case today in the federal courts". ${ }^{98}$ To be fair, the legal problems posed by the grants are genuinely difficult. Many grants recognised types of communal and usufructuary land rights that have no exact counterparts in the Anglo-American tenurial system. Many were only casually surveyed, if they were surveyed at all, with very imprecise boundaries. Most grants included certain types of communal lands which derived from medieval Spanish law and which became a feature of property law in colonial New Spain and in the Mexican republic. ${ }^{99}$ Water rights in the arid lands of the American southwest are a particular problem, the private rights to water which are the norm in the western United States lacking any equivalent in the Civil law systems of the colonial Spanish empire and the Mexico. A further dimension of the complexity is that sometimes there were conflicts between American Indian nations and the descendants of grantees, as was the case with the Pueblo grants: a conflict in which John Collier, Cohen's superior, was as a prominent supporter and advocate for the Pueblos directly involved. ${ }^{100}$

96 See Daniel Walker Howe What God Hath Wrought: The Transformation of America, 1815-1848 (Oxford University Press, New York, 2007) 809-10. Howe sees the most tragic victims of the aftermath of Guadalupe Hidalgo as the tribal Indians of California, who following the Treaty and the admission of California to the Union in 1850 "were exposed to a shocking process of expropriation, disease, subjugation, and massacre that historians today sometimes call genocide": ibid, 810. (It does not follow that the treatment of these people by the Spanish or the Mexicans was especially benevolent, but certainly their circumstances worsened after California joined the Union.)

97 See Gomez, above n 94, 1074.

98 Ed Newville (Comment), "Pueblo Indian Water Rights: Overview and Update on the Aamodt Litigation" (1989) 29 Natural Resources Journal 251 (referring to New Mexico v Aadmodt (1977) 537 F 2d 1002).

99 See Gomez, above n 94, 1041.

100 On Collier's role in this complex three-sided dispute between stockmen, Pueblo Indians and Hispano grantees see David Dinwoodie "Indians, Hispanos and Land Reform: A New Deal Struggle in New Mexico" (1986) 17 The Western Historical Quarterly 292. 
The leading scholar of the legal history of the Spanish and Mexican grants in United States law is Malcolm Ebright, author of a well-reviewed study of the subject published in 1994. ${ }^{101}$ This book, a richly-documented and temperately-worded analysis of the fate of a number of grants in northern New Mexico, paints a picture of frustration, disappointment, unfair treatment by state and federal agencies and sometimes outright fraudulent dispossession as seen from the perspective of the grantees. According to Ebright:

Many of the case studies in this book have revealed injustices in the adjudication of Northern New Mexico's land grants. The San Joaquín grant lost its common lands because of the Sandoval decision and those lands are now part of the Santa Fe National Forest. The Embudo grant was rejected entirely because of a failure to recognize the reality of custom in New Mexico. The common lands of the Las Trampas grant were lost to speculators with the aid of the court-sanctioned partition suit. By documenting the unfairness and injustices that accompanied land loss in New Mexico, history can be made to bear witness to current policy and legal decisions affecting New Mexico's land and water resources. When Bureau of Land Management policy required the Embudo grant residents to buy back their homes from the government after the same government had unfairly acquired most of the grant, then at least let these facts be known. When, in Tierra Amarilla, a community-based weaving and sheepraising cooperative is not able to use state government land for grazing its sheep, at least let it be known that the same land was once communal grazing land of the Tierra Amarilla grant, lost due to the unfairness of the Surveyor General system. And when residents of the Las Trampas grant are arrested and convicted for cutting trees without a Forest Service permit, let us recall that this land was once grant common lands acquired by the U S government with knowledge that the settlers had rights to the timber which the government is now unwilling to recognize.

Far from the litigation over the Spanish and Mexican grants being a conduit for the flow of Spanish legal ideas into American law, the opposite seems to have been the case. Mexican Americans were disadvantaged by their lack of familiarity with the concepts and procedures of Anglo-American common law, as Ebright and other commentators have shown. And far from accommodating the law to Spanish legal ideas, in fact - according to one commentator - the "appalling ignorance of Hispanic law in a common law judicial system bound to uphold it made justice a chimera at best". ${ }^{102}$ Weber believes that in the American southwest generally "the widely respected Spanish legal system was rejected", and cites the view of the California Senate in 1850 that, supposedly, Spanish law "was based on the crude laws of a rough fierce people, whose passion was war and whose lust was conquest". ${ }^{103}$ Other writers have argued that "civil law formalities and

101 Malcolm Ebright Land Grants and Lawsuits in Northern New Mexico (University of New Mexico Press, Albuquerque, 1994). See for example review by Michael Meyer (1995) 42 Ethnohistory 673.

102 Meyer, ibid, 674.

103 David Weber "The Spanish Legacy in North America and the Historical Imagination" (1992) 23 The Western Historical Quarterly 5, 10. 
principles of the colonial era have often been misunderstood by the lawyers and judges of the United States trained in the English common law". ${ }^{104}$ Professor Howe has written that the typically Mexican Americans lost their property "unfamiliar as they were with the English language or Anglo-American land law, and surrounded by newcomers eager to take advantage of them and obtain title to their holdings by fair means or foul". ${ }^{105}$ Specifically, the principal United States Supreme Court decision on Spanish grants, United States $v$ Sandoval, ${ }^{106}$ - which held that under Spanish and Mexican law the sovereign retained a fee title (dominium) over granted common lands, which following Guadalupe Hidalgo passed to the government of the United States - has been criticised in contemporary scholarship as wrongly decided and based on a misunderstanding of Spanish legal principles. ${ }^{107}$ Cohen's claim that litigation over the grants saw a significant reception of Spanish legal principles has to be rejected as lacking in foundation.

In fact the expansion of the United States following the war with Mexico and the Treaty of Guadalupe Hidalgo led not to an incorporation of "Spanish" legal concepts into American law, but rather to a massive expansion of the common law at the expense of Spanish and Mexican Civil law. One could go further and, taking a "Pacific" rather than a "hemispheric" standpoint, see this as part of the emergence of a common law Pacific in the early and mid-nineteenth century. California, formerly part of Mexico, became a state of the Union in 1850 and is today one of the biggest and most important common law jurisdictions in the world. On the other side of the Pacific, New South Wales was established in 1788 and in the 1830s important new common law jurisdictions began in Victoria and South Australia. New Zealand became a British colony in 1840 and was granted a constitution in 1852, not long after California achieved statehood. Settlement in Oregon began in earnest in the 1840s and Oregon became a state in 1859; American settlement around Puget Sound began in 1846 and Washington became a state in 1889; the colony of Vancouver Island (later British Columbia) was established in 1849. It seems that this is actually the real story: One of common law expansion into the Pacific periphery. ${ }^{108}$ For good or ill, it is the common law which now controls

104 Charles T DuMars and Michael J Rock "The New Mexico Legal Rights Demonstration Land Grant Project: An Analysis of the Land Title Problems in the Santo Domingo de Cundiyo Land Grant" (1977-78) 8 NM L Rev 1.

105 Howe, above n 96, 810 .

106 United States $v$ Sandoval (1897) 167 US 278

107 See especially Gomez, above $\mathrm{n} 94$. This is a very full and comprehensive discussion of the relevant aspects of Spanish property law that is essential background to the land grants. Sandoval is also criticised by Richard D Garcia and Todd Howland in "Determining the Legitimacy of Spanish Land Grants in Colorado; Conflicting Values, Legal Pluralism and Demystification of the Sangre de Cristo/Rael Case" (1995) 16 Chicano-Latino Law Review 39

108 See generally Stuart Banner, Possessing the Pacific: Land, Settlers and Indigenous People from Australia to Alaska (Harvard University Press, Cambridge (Mass), 2007). 
the destiny of millions of indigenous peoples in the western United States, Canada, Australia and New Zealand.

\section{Indian Diplomacy and the Reception of Spanish Law}

A final mode of reception discussed by Cohen arose from the actions of the Indians themselves. Unlike recognition through international law and recognition by treaty Cohen's third mode of reception is comparatively complex. In Cohen's words: ${ }^{109}$

Finally, one must recognize that throughout the formative period of our Indian law the Indians themselves had a great deal to say about the disposition of their territory. For a long time they outnumbered the white immigrants, and while at first inferior in weapons they speedily acquired and mastered the white man's firearms. Moreover they knew vastly more about their land and its agricultural and military uses than did the newcomers. By throwing their weight behind the British they played a decisive role in wiping out the French empire in North America. Their attitude towards Spain was a matter of great concern to British and American statesmen through the eighteenth and well into the nineteenth centuries. Britain and, later, the United States were in a very real sense competitors of Spain for Indian favor, and they could not hope to win that favor if they offered less than attractive terms. If the Indians could gain security for their lands and respect for their tribal autonomy from Spain, they were not likely to accept the protection of Britain or that of the United States on less than favorable terms. Thus, in the competition for acceptance, the doctrine of Indian rights first advanced by Vítoria had such an appeal to the Indians that Britain and the United States both felt compelled to accept it as a basis of bargaining. Later, of course, the pressure was removed, but then the respect for the sanctity of the plighted word operated to prevent any wholesale repudiation of those principles which had once been dictated by practical necessity.

Cohen's suggestion seems to be that competition between Spain, France and Britain for control of North America allowed the Indian nations to play one off against the other and, in a sense, to gain the best bargain for themselves. Given that Spanish law prohibited Indian enslavement and respected Indian autonomy the other imperial powers were obliged to follow suit, as was the newly independent United States after the Treaty of Paris.

This is a neglected argument of Cohen's, most commentary focusing on international law, Vítoria, and the Marshall decisions. Cohen was writing at a time when the role played by Indian nations in the $18^{\text {th }}$ century geopolitics of North America did not feature very prominently in either English or American historiography relating to the history of North America in the $18^{\text {th }}$ century. Recent studies of the Seven Years' War - known as the French and Indian war in the United States and the American Revolutionary War are paying much closer attention to the role of the Indians in

109 Cohen "Spanish Origin", above n 1, 19-20. 
the drama, with the result that a much more nuanced history is emerging. ${ }^{110}$ In this area recent historical work has dramatically confirmed - in a general sense - Cohen's insight into the role of the Indians as a vitally important component of American geopolitics in the $18^{\text {th }}$ and $19^{\text {th }}$ centuries. Cohen is certainly right in seeing that the imperial powers competed for Indian support, and that the Indians weighed up the options carefully before deciding who they would back and who they would oppose.

It is sometimes assumed that Spain did not enter into treaties with the Indian nations to any significant extent, but this is not so. Treaty-making in the "Spanish borderlands" of northern New Spain, in the area roughly corresponding to the American southwest today, as well as the Mexican states of Chihuahua, Coahuila, Sonora and Nuevo Leon was a relatively late phenomenon in colonial history but it certainly did happen. ${ }^{111}$ Resting on the theory of papal grants, the Spanish initially saw the Apaches, Comanches and other groups of the southwest as subjects; if they resisted the Crown they were simply rebels. In the later part of the $18^{\text {th }}$ century this juristic theory, hardly a realistic one on the northern frontiers of the Spanish colonial empire, was abandoned in favour of a new policy of negotiations and treaty-making. In making this change, Spanish frontier officials were both adapting to political realities and following the approach taken by other European powers in North America, particularly by France. David Weber has argued that in the later $18^{\text {th }}$ century "trade, treaties and toleration, previously subordinate to force, became the cornerstones of a new French-

110 On the Seven Years' War see now Fred Anderson Crucible of War: The Seven Years' War and the Fate of Empire in British North America, 1754-1766 (Alfred A Knopf, New York, 2000). This conflict, writes Anderson, was "the most important event to occur in eighteenth-century North America", ibid, xv. Anderson describes this great imperial conflict as "as a theater of intercultural interaction, an event by which the colonists of New France and British North America came into contact both with metropolitan authorities men who spoke their languages but who did not share their views of the war or the character of the imperial relationship - and with Indian peoples, whose participation as allies, enemies, negotiators, and neutrals so critically shaped the war's outcome", ibid, xx. See also Fred Anderson The War that Made America: A Short History of the French and Indian War (Penguin Books, New York 2005). On the Indian nations in the American Revolutionary War see Colin G Calloway The American Revolution in Indian Country: Crisis and Diversity in Native American Communities (Cambridge University Press, Cambridge, 1995); Allan Taylor The Divided Ground: Indians, Settlers, and the Northern Borderland of the American Revolution (Alfred A Knopf, New York, 2006). A classic text is Richard White The Middle Ground: Indians, Empires and Republics in the Great Lakes Region, 1650-1815 (Cambridge University Press, Cambridge, 1991). On the role of tribal Indian peoples in the geopolitics of the southwest see for example Thomas Kavanagh The Comanches: A History, 1706-1875 (University of Nebraska Press, Lincoln, 1996); Peka Hämäläinen The Comanche Empire (Yale University Press, New Haven, 2007).

111 Charles Gibson, a prominent historian of the Aztec (Nahua) people has argued that generally Spain, unlike Britain and France, did not enter into formal written treaties with Indians: Charles Gibson "Conquest, Capitulation and Indian Treaties" (1978) 83 American Historical Review 1; for much of the history of the Spanish colonial empire that may have been the case, but Weber's view is that in the 1780s "written agreements became commonplace in Spanish North America due, almost certainly, to the influence of Spain's rivals not only on its policy, but on Indians themselves who demanded written instruments": Weber Spanish Frontier in North America, above n 11, 444. 
inspired Indian policy". ${ }^{112}$ There had been oral understandings and arrangements before, but in the 1780s Spanish colonial officials moved to negotiating written agreements on the French model. Juan Bautista de Anza, governor of New Mexico from 1778-1787, concluded a treaty with the Comanches in February 1786, which led to peace between the Spanish and the western Comanches for many years. ${ }^{113}$ The treaty was essentially a treaty of peace, friendship and an agreement to remodel commercial relations between the Comanches and the Spanish; the discussions took place at Santa Fe, the capital of New Mexico, with Anza speaking for the Crown and the Comanches represented by a prominent chief named Ecueracapa. As a token of Spanish friendship Anza gave to Ecueracapa a sabre and a Spanish flag; and Ecueracapa returned a Spanish captive, Alejandro Martin, captured some years previously. ${ }^{114}$ Reciprocal exchanges of this kind were standard fare in negotiations conducted by the French, but were a new departure on the Spanish frontiers. Thus there were certainly diplomatic relations between Spain and the Indians, in the same way that there were treaties with the English and the French. This goes some way to confirm Cohen's broader point: relations with the Spanish could be a process of negotiation and accommodation with the Indians playing an important role in their own right.

Cohen is, however, not only claiming that Indians were important and autonomous political actors, but more specifically that Spanish willingness to recognise Indian autonomy in a sense upped the stakes and obliged Spain's imperial competitors to do likewise. Cohen offers no evidence for this particular claim. One historian who has considered competition between the imperial powers for Indian support is David Weber, probably the leading American historian of the Spanish frontiers writing today. Weber in fact argues that in terms of trade and commerce Spain was actually the least attractive option as far as the Indian nations were concerned. The British offered the best trade goods to the Indians and paid the highest prices. The French countered this by skilled and imaginative diplomacy: by treating the Indians as equals, "learning their language, marrying them, and making few claims on Indian lands". ${ }^{115}$ Spain ranked a distant third: ${ }^{116}$

With its declining metropolitan economy, retrograde mercantile policies, and insistence on proselytizing its customers, Spain lost ground to its competitors. Although France had seized the heartland of the continent and its Indian trade, in the long run England proved to be Spain's most formidable rival - and France's as well.

112 Weber Spanish Frontier in North America, above n 11, 230.

113 See ibid; Kavanagh, above n 110, 112-114.

114 Ibid, 112.

115 Weber Spanish Frontier in North America, above n 11, 178.

116 Ibid. 
Nevertheless the points made by Weber do not quite address Cohen's argument that Spanish policy and ideas obliged Spain's competitors to compete with the Spanish on ideological grounds and in this way indirectly reinforced the intellectual legacy of Vítoria, Las Casas and the other Spanish theologians of the $16^{\text {th }}$ century. One indisputable fact about the Spanish colonial empire was that Indian slavery was outlawed in the dominions of the Spanish Crown - although it is also true, as noted above, that notwithstanding the formal prohibition of slavery certain types of quasi-slavery, such as the oppressive encomienda, mita, and repartimiento systems had a long life in some parts of the empire. It is the case as well that the prohibition of slavery had a lot to do with the efforts of the Spanish $16^{\text {th }}$ century theologians. It may be that had enslavement of Indians been permitted in Spanish law, then the French and the English may have followed suit and things might have turned out even worse for the North American Indians than they actually did. This has to be put very tentatively, given that the most recent leading study of the enslavement of North American Indians by European colonial powers, which certainly happened whatever the formal position might have been, does not draw any particular distinctions in this regard between the Spanish, the English and the French. ${ }^{117}$ Probably colonists from all three powers would have enslaved North American Indians if they had been able to: but in fact the Indian tribes were formidable opponents and enslavement of them was not a practicable option for the colonists. The French, English and Spanish nevertheless seem to have shared a sense what while outright enslavement of Indians was not ordinarily permissible without some kind of particular justification or excuse, this did not apply to Africans: certainly neither the French, nor the Spanish nor the English showed the least compunction about enslaving Africans. Thus while Cohen's emphasis on the Indians as important political actors in colonial North American history has certainly been shown to be correct, his argument that Indian freedom of action obliged the other powers to adopt the same humane standards as the Spanish has to be regarded as unproven. In actuality the imperial power that accommodated itself most closely to the Indian nations and pursued the most careful and evenhanded negotiations was undoubtedly France.

\section{CONCLUSIONS}

This paper has sought to place Cohen's "Spanish Origin" paper in its own historical context and to review Cohen's specific historical arguments in the light of the developing historiography and legal commentary relating to the Salamanca jurists and to the Spanish colonial empire. The conclusion can only be that none of Cohen's arguments have stood the test of time very well. The case for a significant "Spanish" contribution to Federal Indian law and to aboriginal title law generally seems unconvincing. Cohen's analysis is generally far too kind both to the Spanish empire itself, and to Federal Indian law. What remains as valuable, however, is the efforts that both Felix

117 Alan Gallay The Indian Slave Trade: The Rise of the English Empire in the American South, 1670-1717 (Yale University Press, New Haven and London, 2002). See especially Gallay's comparison of Spanish and English attitudes towards Indian enslavement, ibid, 45-48. 
Cohen and John Collier made to see the history of Indian-European relations in a comparative American context, as part of a larger story that included Mexico and South America. This vision is in turn likely to have been inspired by developments in American historiography in the 1920s and 1930s.

This article, although based on a celebrated law review article dealing with the foundations of Federal Indian law, has ended up mostly as a historiographical discussion. It is not suggested that Cohen was unaware of the actual fate of the tribal Indians of North America: he, better than anyone, knew full well what happened in reality to the Cherokees after the Marshall decisions, or to the "removed" tribes of the southwest in Oklahoma, or - most tragically of all - to the Indians of California after Guadalupe Hidalgo. Nor did he keep silent after the policies of the Indian New Deal were sent into reverse in the Truman and Eisenhower years. Few have been better informed about Indian affairs or history than he. In fact one is left wondering whether he could have really taken seriously - as historical propositions - the arguments that he advanced in his article. To put it another way, Cohen's article was only secondarily a historical discussion, or, rather, it was a policy paper disguised as a historical discussion. That does not mean that Cohen's historical arguments are without interest. In seeking to test Cohen's arguments against more recent historiographical developments the object is certainly not to show that Cohen was a poor historian but rather to use his ideas as a springboard for a review of the legal and historical literature relating to a range of historical propositions that Cohen was the first, and, as far as I am aware, the last, to link together: international law, Hispanic land claims and Indian treaties.

As has been emphasised already, probably Cohen was less interested in making a contribution to legal historiography than he was in helping to protect the gains in Indian law and policy made after 1934. This becomes more clear when Cohen's essay is set alongside the publications of his superior, John Collier, written at the same time and which pursue very similar themes. Of course Cohen's and Collier's moral and political commitment to a re-energised Federal Indian law based on a repudiation of assimilation, the ending of allotment and the establishment of tribal constitutions, all based in turn on a belief in tribal sovereignty, still stand on their own terms. Whether Cohen and Collier's appeal to history was justified is of no real importance when it comes to assessing their achievements. Cohen's history may have turned out to be a little shaky but this does not in the end amount to a significant reflection either on his ideals or his own place in history. 